\title{
Large-scale solar thermal systems in leading countries: A review and comparative study of Denmark, China, Germany and Austria
}

\author{
Daniel Tschopp ${ }^{\mathrm{a}}$, Zhiyong Tian ${ }^{\mathrm{b}, *}$, Magdalena Berberich $^{\mathrm{c}}$, Jianhua Fan ${ }^{\mathrm{d}}$, Bengt Perers ${ }^{\mathrm{d}}$, \\ Simon Furbo ${ }^{\mathrm{d}}$ \\ ${ }^{a}$ AEE - Institute for Sustainable Technologies, Feldgasse 19, 8200 Gleisdorf, Austria \\ ${ }^{\mathrm{b}}$ Department of Civil and Environmental Engineering, Norwegian University of Science and Technology, 7491 Trondheim, Norway \\ ${ }^{\mathrm{c}}$ Solites, Steinbeis Research Institute for Solar and Sustainable Thermal Energy Systems, Meitnerstraße 8, 70563 Stuttgart, Germany \\ ${ }^{\mathrm{d}}$ Department of Civil Engineering, Technical University of Denmark, Brovej Building 118, Lyngby, 2800, Denmark
}

\section{H I G H L I G H T S}

- Comprehensive analysis of country-specific boundary conditions and success factors.

- National heat supply systems and incentive policies are essential.

- Role of district heating utilities in Denmark for solar district heating success.

- Technological solutions and best practice examples of large-scale systems.

- First-hand market research on China shows higher market penetration than assumed.

\section{A R T I C L E I N F O}

\section{Keywords:}

Large-scale solar thermal systems

Renewable heat

Cost efficiency

Energy policy

Country analysis

\begin{abstract}
A B S T R A C T
Large-scale solar thermal systems are a cost-efficient technology to provide renewable heat. The rapid market growth in the last decade has been concentrated on a small number of countries, with the outstanding position of Denmark followed by China, Germany and Austria. This paper provides a comprehensive overview of the market and common technological solutions for large-scale solar thermal systems in these countries. Country-specific factors, including solar resources, heat supply systems, competing technologies, promotion schemes and business models, which put these countries in a leading role, are analyzed in detail using an integrated assessment framework. For each country, a best practice solar heating system is introduced. The analysis shows that heat supply by large-scale solar thermal systems is a mature technology with a broad field of applications and that mainly country-specific boundary conditions regarding the heat supply system and incentive policy are responsible for the preeminent role of these four countries. The unique role of district heating utilities in Denmark, which are subject to a national emissions trading system and often act both as investors and operators of largescale solar thermal systems, can serve as a role model for other countries.
\end{abstract}

\section{Introduction}

About $50 \%$ of the total final energy consumption in the world attributes to heat used in the residential and industrial sector [1]. Space heating and domestic hot water can reach up to $80 \%$ of the final energy consumption in the residential sectors of EU countries [2]. $84 \%$ of the heating and cooling energy consumption in the EU is still based on fossil fuels while only $16 \%$ is provided by the renewable energy sector [3]. To reach the climate and energy goals of the Paris agreement and international and national energy policies, decarbonization and energy efficiency increases cannot be limited to the electricity sector. The transformation of the heat sector must also be accelerated [4].

Solar thermal supply of low temperature heat demand (not exceeding $95{ }^{\circ} \mathrm{C}$ ) can play a significant role in the future energy mix and could reach more than $16 \%$ of total final energy use (16.5 EJ) for low temperature heat by 2050 worldwide [5]. For many European countries, the overall solar thermal potential is estimated to be in the range of $3-12 \%$ of the total heat production [6]. There are good prospects for China as well. The Chinese government aims to reach 3.5 billion $\mathrm{m}^{2}$ space heating area using renewable energies by the end of 2020 , while

\footnotetext{
* Corresponding author.

E-mail addresses: tianzy0913@163.com, zhiyong.tian@ntnu.no (Z. Tian).
} 


\author{
Nomenclature \\ CHP Combined Heat and Power \\ CPC Compound Parabolic Collector \\ DH District Heating \\ DHW Domestic Hot Water \\ DNI Direct Normal Irradiance \\ ETC Evacuated Tube Collector \\ ESCo Energy Service Company
}

FPC

$\mathrm{LCOH}$

O\&M

PTC

PTES

SDH

$\mathrm{SH}$

TRY

\author{
Flat Plate Collector \\ Levelized Cost of Heat \\ Operation and Maintenance \\ Parabolic Trough Collector \\ Pit Thermal Energy Storage \\ Solar District Heating \\ Space Heating \\ Test Reference Year
}

the area of space heating using renewable energies by the end of 2016 was only 700 million $\mathrm{m}^{2}$ [7]. The total installed area of solar thermal systems in China should be above 800 million $\mathrm{m}^{2}$ by the end of 2020 [7]. With an estimated turnover of 16.9 billion USD in 2017 and 672,000 people working on production, installation and maintenance of solar thermal systems worldwide, the solar industry is already a major economic factor [8].

Solar thermal heat supply systems range from small installations for single-family houses, medium scale installations for multi-family houses, smaller heating networks and process heat plants to large-scale solar thermal plants [9]. Economies of scale make community sized SDH systems perform better in terms of system efficiency and energy costs than separate heat supply systems of single buildings [10]. Largescale solar thermal plants are defined as systems with more than $500 \mathrm{~m}^{2}$ collector aperture area or $350 \mathrm{~kW}$ nominal thermal power [8]; a factor of $0.7 \mathrm{~kW}$ thermal power per $\mathrm{m}^{2}$ collector aperture area is typically used to convert collector area to nominal power [11]. The most common application of large-scale solar thermal systems is heat supply to DH networks and local heating networks with residential, commercial and public buildings, which makes up $88 \%$ of the total installed and operated capacity. Solar process heat, which is mainly used in the mining, textile and food industry, amounts to $12 \%$ [12].

By the end of 2018, the total installed and operated capacity of large-scale solar thermal systems reached $1.55 \mathrm{GW}\left(2.2\right.$ million $\mathrm{m}^{2}$ collector area) [8]. Although the installed capacity in large-scale systems is still relatively small with less than $1 \%$ of the total installed capacity of small-scale solar thermal systems, it is quickly rising in importance. The market has been experiencing rapid growth recently, with an average $15.5 \%$ increase per year in the main markets of Denmark, China, Germany and Austria between 2010 and 2018. This contrasts the global solar thermal market, which has been shrinking by $2.8 \%$ per year in the same period [13].

The driving force for large-scale solar thermal systems has been SDH applications in Denmark, where by the end of 2018 a total of 118 plants with a capacity of $970 \mathrm{MW}$ were in operation, making up $63 \%$ of the capacity worldwide [8]. Denmark is followed by China (212 MW, 55 systems). China could become the leading market driver and surpassed Denmark regarding newly installed capacity in 2017 and 2018 for the first time. Market data for China might substantially underestimate the total and newly installed capacity (see Section 4.1). Germany (45 MW, 27 systems) and Austria (27 MW, 23 systems) successfully established niche markets for large-scale systems, ranking number three and four if the two big solar process heat plants in Oman (104 MW) and Chile (28 MW), which were singular installations and not part of a broader market development in Oman and Chile respectively, are not considered. Besides these four countries and Oman and Chile, only SaudiArabia and Sweden reach more than $20 \mathrm{MW}$ total installed capacity in large-scale solar thermal systems. Denmark, China, Germany and Austria have a combined market share of $81 \%$ in the world [8].

The deployment of large-scale solar thermal systems being concentrated on a small number of countries and the diametrical developments of the markets for large-scale and small-scale systems call for a twofold analysis. First, a country-by-country analysis of Denmark, China, Germany and Austria is used to identify conducive boundary conditions for large-scale solar thermal systems. These countries are particularly suitable for such an analysis, as they are home to the four main markets for large-scale solar thermal systems and have their own distinct boundary conditions. Second, the success of large-scale solar thermal systems can be analyzed on a technological level, addressing the benefits and challenges of upscaling solar thermal systems.

Although heat supply by large-scale solar thermal systems is a mature technology, empirical work on its success factors is still scarce. Most of the literature such as [6], focuses on the potential of the technology rather than existing conducive boundary conditions, or remains on a strategic level, lacking a clear link to existing markets. Available market statistics, like Solar Heat Worldwide [8], do not provide in-depth analysis of market dynamics. Recent review articles such as [14], are limited to the technology.

The article fills this gap by providing the first comprehensive and comparative study on large-scale solar thermal systems in the most successful countries (Denmark, China, Germany and Austria), in order to identify crucial country-specific factors which made these countries successfully deploy large-scale solar thermal systems. The integrated assessment framework includes geographical, techno-economic and environmental boundary conditions. Risk minimizing strategies such as yield prediction and performance guarantees, which have been largely neglected in research, are analyzed. The article highlights the unique role of district heating utilities in Denmark for the deployment of largescale solar thermal systems. Country-specific success factors are related to market characteristics, which evolved from the national boundary conditions. A new market survey on China, whose market is still very little documented, is provided based on first-hand data collection from plant designers and institutions. The article also summarizes key features of wide-spread technological solutions. Both large-scale solar thermal systems for heating applications and solar process heat are included in the analysis. Additionally, a best practice example for each country is provided to demonstrate a successful project within the country-specific boundary conditions. The analysis of the technological solutions is limited to the solar collector circuit, which consists of one or multiple collector arrays and forms the core part of large-scale solar thermal systems.

\section{Previous work and analysis framework}

An extensive study on SDH identified 24 strategic approaches in the categories funding, financing, regulations and taxes and additional measures to facilitate the success of SDH [15]. According to the study, the success of SDH is a multifactor combination of technological conditions (e.g. low cost of solar thermal integration into existing networks), energy policy measures (e.g. taxes on fossil fuels), financing and business models (e.g. cheap loans) and most importantly low LCOH (e.g. realization of economies of scale). In Denmark, solar thermal systems bigger than $7 \mathrm{MW}\left(10,000 \mathrm{~m}^{2}\right)$ with diurnal heat storage reach LCOH of $36 € /$ MWh on average, and the LCOH of systems bigger than $35 \mathrm{MW}\left(50,000 \mathrm{~m}^{2}\right)$ with seasonal heat storage (which is a major cost factor) are $49 € / \mathrm{MWh}$ [16]. The optimal integration of seasonal storages in SDH systems regarding design and operation were studied by [17]. Another study highlights the importance of cheap land for 
ground-mounted collector arrays [18]. The study concludes that economies of scale of solar thermal systems with ground-mounted collector arrays often compensate for the extra cost of transmission pipes if the collector array is set up outside a town as opposed to smaller solar thermal systems on the rooftops within a town. As highlighted by [19], an important success factor is also the involvement of one or several strong local actors with the knowledge and interest to build solar thermal systems, such as local city governments, utilities and manufacturers. The lifetime of the solar collectors is very important too. It has an influence on the possibilities to get loans for a plant [20].

In a broader perspective, the construction and operation of largescale solar thermal systems is the realization of a renewable energy potential. A generic and integrated approach to asses renewable energy potentials is provided by [21]. According to this approach, the renewable energy potential is divided in a geographical, technical and economic potential, followed by the implementation potential which determines if and how fast the geographical, technical and economic potential is realized, e.g. through subsidies, feed-in tariffs, business models and regulations. In this paper, crucial aspects of these four categories are addressed. A core part of the techno-economic potential lies in the solar collector circuit technology, which is described on a transnational level, as it is available in all leading countries and accrues to the technology as a whole. Transnational factors intermingle with country-specific boundary conditions. Table 1 provides an overview of the used categories to describe crucial aspects of the four potentials.

A systematic techno-economic analysis of system parts other than the solar collector circuit is beyond the scope of this paper, but some aspects of the overall system design, operation and integration are highlighted within the best practice examples in Chapter 6. Although the dimensioning, design and operation of the solar collector circuit depends on the overall system integration and control strategy, many techno-economic innovations for the solar collector circuit can be treated relatively independently of the remaining system. Furthermore, local conditions within a country can influence the renewable energy potential [22]. They are not part of this analysis and should be addressed in subsequent studies in more detail where necessary.

\section{Large-scale solar collector circuit technology}

The solar collector circuit consists of one or multiple collector arrays, typically operated with an anti-freezing liquid and separated by a heat exchanger from the demand side. Depending on the system design, plants include diurnal or seasonal heat storages and are combined with auxiliary heat sources, such as biomass and fossil fuel boilers, heat pumps, power-to-heat and waste heat. For DH networks, different options exist for system integration, such as return/supply connection (water taken from the return pipe of the DH network is fed to the supply line) and centralized/decentralized feed-in [14]. In general, the overall aim of the plant design is to minimize the LCOH by maximizing the solar yield over the lifetime of the plant while keeping the investment and O\&M cost low. As large-scale solar thermal systems require high initial capital investment, risk minimizing strategies are needed as well. In this chapter key techno-economic features of the collector array technology, which are of special interest to large-scale applications, are summarized.

\subsection{Collector design}

Flat plate collectors (FPC) are the most common collector technology in the European market for large-scale systems [8]. Collectors have undergone a strong development in the last decades with regard to efficiency, quality, cost reduction and long-term reliability [20]. Collector modules used in large collector arrays usually have areas of 12 to $14 \mathrm{~m}^{2}$ [23], whereas collector modules in small-scale applications have typically areas of 2 to $3 \mathrm{~m}^{2}$ [24]. The larger size makes installation faster and more cost-effective by reducing the number of hydraulic connections and mounting support. The large size also reduces heat losses by fewer cold bridges [25]. Aluminum strips are commonly used as absorbers. They are cheaper than copper, which was the main material in the last decades [24]. The absorber has a selective coating in order to absorb most of the radiation within the solar spectrum and have low emissivity of heat radiation at higher temperatures [26]. Given the large size of the collectors, several absorber pipes are connected in parallel, running from the inlet to the outlet manifold, to reduce the pressure losses. To reduce the heat losses of FPCs at higher operating temperatures, collectors with glass and foil or double glass instead of single glass are used. In some cases, collectors with single glass and with foil/double glass are deployed in the same collector array, the former at the beginning of the row and the latter at the end, to achieve the most cost-effective row composition [27]. For higher temperatures in the range of $80-100{ }^{\circ} \mathrm{C}$, the efficiency of FPCs decreases due to increased thermal losses. Evacuated tube collectors (ETC) are more efficient than FPCs in higher temperature ranges and have been also successfully deployed in large-scale systems. Parabolic trough collectors (PTC) have been developed to achieve good efficiency in the temperature range of $70-150{ }^{\circ} \mathrm{C}$. An advantage of PTCs lies in the reduction of the absorber surface by concentrating the radiation with mirrors. They have attracted attention for large-scale applications in recent years [28]. For ground mounted FPCs, mounting techniques using pile-driven or screw-in foundations instead of concrete pedestals have become widespread recently, because it allows faster and less intrusive mounting.

As collector designs have reached a very high standard, the focus has shifted to the optimization of the manufacturing process through automation. Large FPC manufacturers like Arcon-Sunmark A/S or GREENoneTEC GmbH use almost fully automated assembly lines. The main cost reduction has been reached in the production of the absorber. For harp and meander absorbers, which are most commonly used for large-scale FPC, tailoring of the manifold and absorber pipes, welding of the absorber pipes to the absorber plate and brazing the absorber pipes to the manifold have been completely automated. Meander absorbers use fewer absorber pipes compared to harp absorbers, which reduces the number of brazing spots. Robot manufacturing has brought down the share of labor cost [29].

\subsection{Hydraulic layout}

The objective in connecting collectors is to increase their hydraulic length, that is, the thermally active pipe length the fluid must flow through between inlet and outlet pipes. A higher thermal length allows to achieve a large and useful temperature increase with a low volume flow [30]. A homogenous flow distribution is important for an efficient operation. Heterogeneous flow distribution causes uneven temperature distribution in the collector array. In the worst case, it can lead to partial stagnation if parts of the collector array reach the boiling temperature of the heat transfer medium [31]. The main influence on the

Table 1

Integrated analysis framework to assess the solar thermal potential.

\begin{tabular}{llcl}
\hline Factor & Category & Level & Section \\
\hline \multirow{2}{*}{ Geographical } & Solar resources & $\mathrm{C}$ & 5.1 \\
Techno-economic & Collector design & $\mathrm{T}$ & 3.1 \\
& Hydraulic layout & $\mathrm{T}$ & 3.2 \\
& Plant control & $\mathrm{T}$ & 3.3 \\
& Solar yield prediction and performance & $\mathrm{T}$ & 3.4 \\
& guarantees & & \\
& Heat demand and heat supply infrastructure & $\mathrm{C}$ & 5.2 \\
& Energy prices of competing technologies & $\mathrm{C}$ & 5.3 \\
& Promotion schemes & $\mathrm{C}$ & 5.4 \\
& Business models and regulations & $\mathrm{C}$ & 5.5 \\
\hline
\end{tabular}

$\mathrm{C}=$ country-specific, $\mathrm{T}=$ transnational. 
flow distribution inside FPCs is the basic hydraulic collector type (harp or meander) and the dimensioning of the absorber and manifold pipes, i.e. the pressure drop ratio between the manifold pipes and the hydraulic elements they are connected to. Additional factors are the friction losses at the T-pieces, connecting the absorber and manifold pipes, and buoyancy effects [32]. Both within the collector and for the whole collector array, the flow distribution is influenced by the mass flow and temperatures. If a homogenous flow distribution is difficult to achieve (e.g. for non-regular layouts or very large fields), putting balancing valves at the entrance of each collector row has proven successful [33]. Additionally, gradually reducing the pipe diameter for the parts of the collector array with less volume flow can help to achieve a more homogenous flow distribution and save piping cost, but this requires exact advance calculations, as subsequent adjustments would be very expensive [30]. Remaining air/gases can disturb the hydraulic flow balance in a collector array and nowadays often vacuum degassing of the heat transfer fluid is used, at least at start-up of a plant [34]. Flow distribution has been a problem during the early stages in the design of large collector arrays, the solutions which have been developed during the last twenty years are now technologically mature.

\subsection{Plant control}

As a basic principle, the system design and control strategy of a large-scale solar thermal system should be smart and simple in order to reduce the complexity of maintenance and service as well as to achieve a high operational reliability. The low-level control of the solar collector circuit is embedded in the upper-level control of the whole solar thermal plant [35]. A minimum feed-in temperature or minimum temperature increase from inlet to outlet (preheating) is typically agreed with the heat customer. Depending on the required temperature level (e.g. the supply temperature of a DH network) and the overall system design (additional heat sources, storages, indirect use of solar thermal energy by heat pumps, etc.), a set point curve for the outlet temperature of the solar collector circuit is determined. The low-level control of the solar collector circuit is typically model-based, whereas the upper-level control can have other control strategies like modelbased predictive control including long-term weather forecasts [36].

To achieve a set point outlet temperature curve, large-scale solar thermal plants use frequency-controlled pumps to adjust the volume flow depending on the inlet temperature, radiation inputs and thermal losses. A simple, but effective approach of a model-based control strategy is to set the volume flow to the level which achieves the desired outlet temperature according to the characteristic curve of the collectors [37], in combination with a moving average filter on the measured solar irradiance. A more advanced approach to factor in the dynamic behavior is to use a finite dimension state space model [38]. The pump is usually switched on as soon as the radiation in the collector plane oversteps a defined threshold and the ambient air temperature is high enough. In the morning and after long non-operation periods, preheating of the collector mass, heat transfer fluid and piping system in the array (and of long connecting pipes if present) is necessary before there is a useful heat gain. The pump is switched off if the available radiation and temperatures do not allow to reach the desired outlet temperature with the minimal volume flow. In order to avoid shortterm operation of the pump, there are usually dead-bands defined for switch-off. The operation of the pump is also stopped if the heat provided by the solar collectors cannot be used (stagnation) [39]. To avoid stagnation and overheating, night cooling can be used to lower the storage temperatures, such that more heat can be fed to the storage on sunny days where the demand is low. If no or a low concentration of frost protection liquid is used in the solar collector circuit, a frost protection mode is activated if low ambient temperatures occur, by using heat from the storage or DH network return side and transferring it to the solar collector circuit. The temperature in the collectors only needs to be heated safely above the freezing point of the fluid [37].

\subsection{Solar yield prediction and performance guarantees}

Large-scale solar thermal systems have very low O\&M costs. The main cost is the electricity of the pumps if the plant is operated alongside a DH plant [18]. An estimate based on Austrian experiences sets O\&M costs to $0.5 \%$ of the investment cost for large-scale FPC fields [40], Danish systems have maintenance costs of about $0.27 € / M W h$. But large-scale solar thermal systems require high initial capital investment. Successful projects do not only need to minimize the $\mathrm{LCOH}$, but also have to develop a strategy to deal with the financial risk. The plant owner is usually paid a fixed price per produced kilowatt hour solar heat if he sells the heat to a third party. Crucial for the economics of a project is the total sold solar heat over the lifetime of the plant. Thus, the solar yield prediction is very important. The solar yield essentially depends on design, components and operation of the plant, load and environmental conditions and their interplay.

The prediction of the solar yield at the planning stage is done with simulation programs, such as TRNSYS [41] and PolySun [42]. Besides the simulation model, the reliability of the solar yield prediction depends on the input data. The crucial inputs are the efficiency parameters of the collectors (component parameter), an accurate estimation of the operating temperatures and load (operating conditions) as well as an accurate prediction of the direct and diffuse irradiance on the collectors (climate data). The efficiency parameters of collectors are obtained by testing a collector under standard laboratory test conditions according to ISO 9806, which offers a stationary and quasi-dynamic test procedure and is certified under the Solar Keymark certificate [43]. In recent years, the quasi-dynamic test procedure has gained popularity as its efficiency parameters describe the collector more accurately under non-stationary conditions than the stationary test and consider variable shares of direct and diffuse irradiance. As the conditions of the collectors tested in the laboratory and their operation in the field can be considerably different (soiling of glass cover, less-than-ideal stress of convection barrier foil, vegetation, etc.), in-situ testing of collectors to build systematic knowledge on the "real-world" performance is important. This is currently investigated in the research projects MeQuSo [44] and ZeKon in-situ [45].

If a new plant is planned, in many cases there is no reliable data about the yearly heat demand and its distribution over the year available. How to gain accurate assumptions of the heat demand still poses a problem for large-scale solar thermal systems, despite the existence of various simple load forecasting methods [46] and more advanced approaches [47]. Besides the load, the solar heat gain depends also on the operating temperatures. The higher the average operating temperature of the collectors is, the lower the efficiency becomes, because of higher heat losses of the collectors. For gas or oil boilers, this problem is much less severe, as the efficiency does not depend on the temperature levels (an exception being condensing boilers) and only to lesser degree on the heat demand (e.g. efficiency reduction due to partial load). The higher the solar fraction covered by the solar thermal system and the smaller the buffer storage capacity compared to the collector area, the higher is usually the dependency of thermal performance on load and environmental conditions. Lowering the solar share reduces this dependency and can be a strategy for risk mitigation.

Furthermore, an accurate prediction of the solar yield requires reliable data on the direct and diffuse irradiance of the location. The quality of the available data needs to be thoroughly investigated [48]. Many countries face a slow increase of the available solar radiation in recent years. Especially the DNI and total radiation on a tilted surface is increasing [49]. The increase can be in the range of $10 \%$ compared to standard long-term data for periods like 1961-1990. The reason for this increase is not fully understood yet, but there is a correlation to emission control especially of sulfur into the atmosphere [50]. The use of modern solar radiation data is therefore recommended for design and sizing of plants. A sensitivity analysis on parameter changes can help to quantify the effects of modeling and input uncertainties to obtain more 
reliable estimates.

Performance guarantees for large-scale solar thermal systems are an increasingly important tool to minimize the risk associated with building a solar thermal plant. The performance guarantee can refer to single components (collectors, storages, etc.) or parts of the plant. A method to check the thermal power output which has been used in Denmark since more than twenty years compares the measured thermal power output against the estimated output based on the collector datasheet parameter when running the collector array under stable conditions close to full power [51]. It has been proposed as an ISO standard, and a working group under ISO/TC 180 is currently elaborating the standard. The main advantage of this method lies in its simplicity and easy applicability. The method is not suitable to check the solar yield for which new test methods are under development [44].

\section{Market overview}

\subsection{Installed capacity}

The newly installed capacity in large-scale solar thermal systems between 2010 and 2018 in Denmark, China, Germany and Austria is shown in Fig. 1. The data includes heating applications and solar process heat. Data for Denmark [52], Germany [53] and Austria [54] is based on regularly conducted market surveys. For China, a new market survey was done. Data from the main designers of large-scale solar thermal systems - Sunrain, Five Star, Linuo - and the institutions China Academy of Building Research, Chinese Academy of Science, IMSIA and Solrico were collected. A distinct characteristic of Chinese DH networks is that they typically only provide space heating (see Section 5.2). DHW systems are mostly installed for local grids, which are not connected to DH networks. These systems can be much larger than $500 \mathrm{~m}^{2}$ collector area. In the market survey on China, only data for space heating and industrial applications were considered. According to these data, there are 55 systems with a total capacity of $212 \mathrm{MW}$ in operation by the end of 2018. As there are plenty large-scale DHW systems and data for space heating and industrial process plants might still be incomplete, the Chinese large-scale market is presumably much bigger. The figures are significantly higher than [8], which list only 21 large-scale solar thermal systems in China.

In 2010, all countries together installed a capacity of $38 \mathrm{MW}$ $\left(55,000 \mathrm{~m}^{2}\right)$. In the record year 2016, a total of $366 \mathrm{MW}\left(523,000 \mathrm{~m}^{2}\right)$ were installed. The main driver was Denmark, with a record of $348 \mathrm{MW}$ $\left(497,000 \mathrm{~m}^{2}\right)$ installed capacity in 2016. In 2017 and 2018 the market declined rapidly, due to a decrease of the installations in Denmark. A major reason was the temporary exclusion of collector arrays connected to DH networks from the Danish emissions trading system (see Section 5.4). For 2019, the Danish market is expected to recover, as a new agreement has been reached, which allows solar thermal systems to rejoin the emissions trading system. Installations in China made a significant step in 2017 and 2018, mainly due to PTC arrays. The market in Germany got a significant boost in 2016, which was caused by a new subsidy scheme and is expected to double in the next years [55]. The Austrian markets had a stable subsidy scheme during the last decade and no clear trend in market development is visible. All markets show a high dependency on promotion schemes (see Section 5.4).

\subsection{System characteristics}

The leading countries exhibit remarkable differences regarding the characteristics of their typical large-scale solar thermal systems (Table 2).

Denmark has a mature commercial market for large-scale solar thermal systems with distinct characteristics. Almost all systems provide heat to DH networks, there are no significant industrial applications. In the typical business case, a large-scale solar thermal plant feeds into an existing DH network and replaces a CHP plant which has become unprofitable due to low electricity prices [56]. All centralized and most decentralized CHP plants in Denmark sell electricity at the market price in the Nordic power market [57]. Selling prices for electricity have significantly dropped since 2010 [58], although in Denmark household electricity prices after taxes are the second highest in the EU [59]. The necessity of cheap and suitable land near DH network supply points typically limits SDH projects to small towns and villages. System sizes have been growing over the last years. Most of the largest SDH plants worldwide are in Denmark. The so far largest FPC system, located in the Danish town of Silkeborg with a capacity of 110 MW $\left(157,000 \mathrm{~m}^{2}\right)$, started its operation in 2017 [16]. For plants without a seasonal storage, system sizes are limited by solar fraction. If the solar fraction becomes too large, heat production can become inefficient due to stagnation during the summer months. Eight plants have seasonal heat storages. Average yearly yields of SDH plants are around $400-500 \mathrm{kWh} / \mathrm{m}^{2}$ (collector aperture area) [60]. Low heat prices can be achieved by highly standardized system concepts, reliable components, low land cost, favorable financing and existing low temperature $\mathrm{DH}$ networks.

China has dominated the market for small-scale solar thermal systems for many years, accounting for $89 \%$ of the installed capacity by end of 2016 [16]. Large-scale solar thermal systems for space heating and industrial processes have only started to be installed in recent years. In comparison to Denmark, where most plants use FPCs, ETCs and PTCs are also widespread in large-scale applications. One $75,000 \mathrm{~m}^{2}$ PTC plant for DH supply was constructed in Inner Mongolia in 2017.

As in Denmark and Austria, large-scale systems in Germany mainly

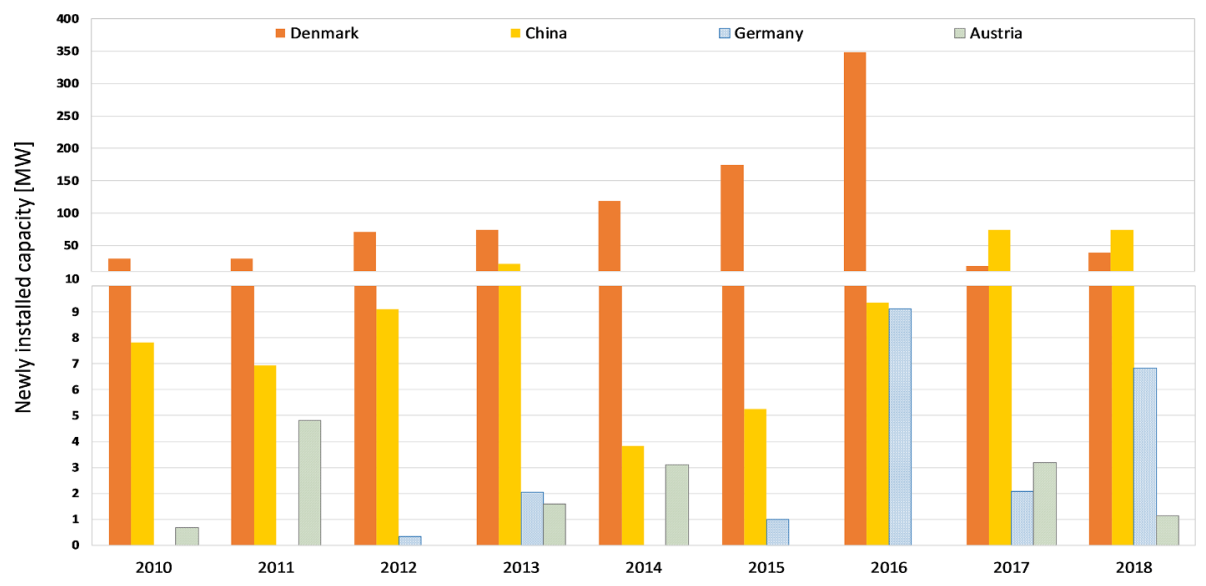

Fig. 1. Development of large-scale solar thermal systems from 2010 to 2018. 


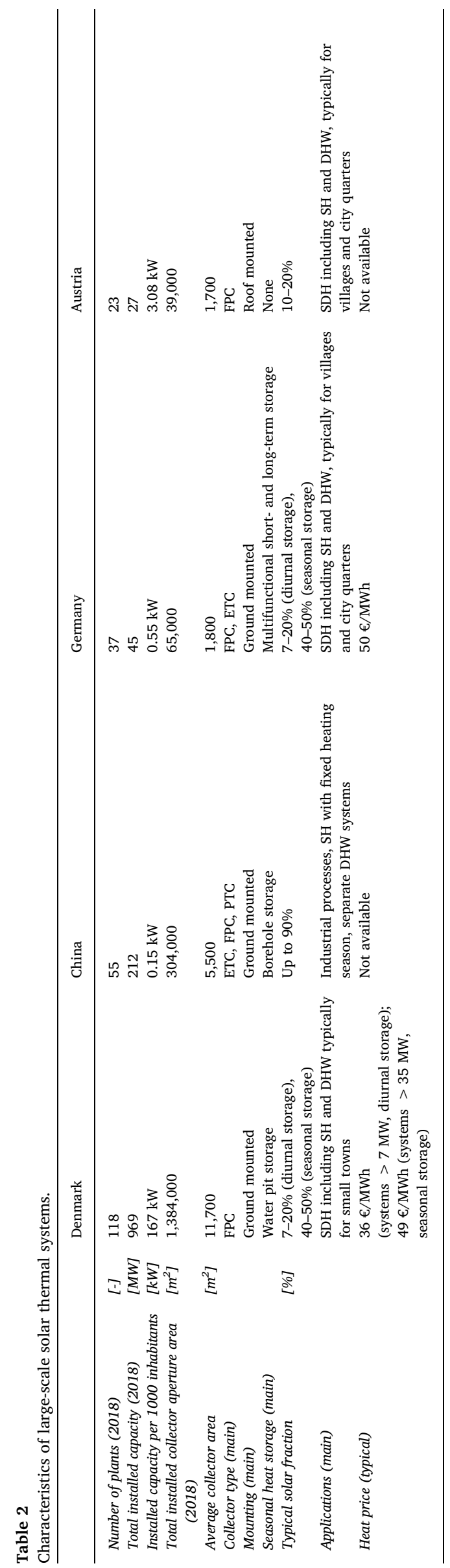

use FPCs, but ETCs have a relatively high share of $34 \%$ of installed collector area. A special system design with ETCs was developed, where the solar collector circuit is operated with water and not with an antifreezing liquid as usual. This gives the possibility to omit the heat exchanger between the solar collector circuit and demand side, but requires heating of the solar collector circuit if temperatures are below freezing point [61]. Germany has a long history of seasonal heat storage deployment. In eleven pilot plants, built between 1996 and 2001, with the aim of reaching $50 \%$ solar fraction, different seasonal heat storage technologies (underground aquifer, borehole, pit and tank storage) were developed and monitored. Multifunctional short- and long-term storages for all heat producers have also been integrated into the system [62]. SDH applications range from small villages and rural areas, to SDH for districts and SDH in cities and urban centers. For cities and urban areas, SDH systems are usually combined with CHP plants, heating plants, waste incineration or industrial waste heat. Large-scale solar thermal plants can be used in a broad variety of industrial processes but this market is much smaller. Realized plants are providing heat for brewing, an absorption chiller in steel production, greenhouses, cleaning processes in food production and car washing [12]. Because of the good incentives, the solar process heat market is expected to grow [63]. Depending on the system size and efficiency of the solar thermal plant, heat production costs below $50 € / \mathrm{MWh}$ can be reached without incentives [39].

The Austrian market is similar to the German market regarding system sizes and applications, although no systems with seasonal storage have been realized yet. Unlike in Denmark, urban applications are widespread. For urban applications, collectors are usually mounted on roofs of tower blocks or boiler houses. This limits the system size. Systems in the medium range of $100-500 \mathrm{~m}^{2}$ are common in Austria, with around eight times more systems built in this range between 2010 and 2016 compared to large-scale systems [64]. Recently, combining large-scale solar thermal systems with heat pumps has become more common.

\subsection{Solar industry}

These four countries also have a strong solar thermal industry. Arcon-Sunmark A/S, the main manufacturer of FPCs in Denmark, installed more than $80 \%$ of the large-scale solar heating plants in Europe as a turn-key supplier [65]. China is the largest producer of ETCs [66] and was the leading country in FPC production in 2017 and 2018 [67]. Chinese companies seek to intensify economic ties with European manufacturers and turn-key suppliers. A joint venture between ArconSunmark A/S and the world's largest collector manufacturer Jiangsu Sunrain Solar Energy was established in 2016 [68]. The Austrian based company GREENoneTEC GmbH, the world's leading FPC manufacturer [69], has been majority-owned by the Chinese Haier Group since 2017 [70]. The Swedish PTC manufacturer Absolicon set up a first production line in Sichuan province [71]. In Germany, the company Ritter XL Solar developed a large-scale solar thermal system concept for ETCs [61]. Consolidation of the solar thermal industry is likely to continue. On April 2 2020, Arcon Sunmark A/S announced that GREENoneTEC $\mathrm{GmbH}$ acquired key assets of its business and the Chinese Solareast Group (which owns the Sunrain and Micoe brands) bought the shares of the Chinese-Danish joint venture [72].

\section{Boundary conditions}

Besides the large-scale collector array technology and the overall system design, operation and integration (which is beyond the scope of this paper), the success of large-scale solar thermal systems crucially depends on country-specific boundary conditions. Each of the four investigated countries provides a particular framework which determines if large-scale solar thermal systems can be economically viable and how successful particular system concepts are. 


\subsection{Solar resources}

The available solar radiation is one of the main factors affecting the solar yield of a large-scale solar thermal plant. For non-concentrating systems with FPCs, the achievable daily yield is usually approximately a linear function of the received total irradiance on the collector plane, where the slope of this function depends on the temperature difference between the operating temperature of the solar collector circuit and the ambient temperature [73]. Lower temperature differences are favorable for the solar yield, i.e. the slope of the curve increases. Concentrating systems deploy tracking to follow the sun and use the DNI. Nontracking collectors have a fixed tilt and azimuth. The yearly irradiance on an optimally tilted and aligned surface is a good indicator for the achievable solar yield for non-tracking collectors. Although overview calculations for some regions exist [74], only data on global irradiance on horizontal surfaces is typically available from weather stations. Subsequently, data on global irradiance is used.

The global irradiance in the four countries is depicted in Fig. 2. Denmark belongs to the Nordic area. The solar radiation is not as favorable as in other regions, such as southern Europe [75]. Global radiation on the horizontal surface is between 1,000 and $1,150 \mathrm{kWh} / \mathrm{m}^{2}$ / year. DNI levels are around $800-1,100 \mathrm{kWh} / \mathrm{m}^{2} /$ year [76]. The winter in Denmark is quite cold, with an average temperature of January and February just above freezing. The summer in Denmark is mild with temperatures about $13-17{ }^{\circ} \mathrm{C}$ [77]. In China, solar radiation resources vary a lot because of China's different geographical situation. The lowest solar radiation areas are located at Chuan-Yu region (SichuanChongqing) with around $950 \mathrm{kWh} / \mathrm{m}^{2} /$ year [78]. The highest solar radiation levels are found in the Qinghai-Tibet Plateau with more than $2,200 \mathrm{kWh} / \mathrm{m}^{2} /$ year. Two thirds of the land areas of China have DNI levels exceeding $1,095 \mathrm{kWh} / \mathrm{m}^{2} /$ year $\left(3 \mathrm{kWh} / \mathrm{m}^{2} /\right.$ day) [79]. Certain regions of the Qinghai-Tibet Plateau have even DNI levels of more than $9 \mathrm{kWh} / \mathrm{m}^{2} /$ day. Solar radiation resources are very high in the cold regions in the west of China and Inner Mongolia. Global radiation in Germany varies from north to south between 1,000 and 1,200 kWh/ $\mathrm{m}^{2} /$ year and DNI between 750 and $1,150 \mathrm{kWh} / \mathrm{m}^{2} /$ year [80]. The longterm average ambient temperature is around $8.9{ }^{\circ} \mathrm{C}$ [81]. In Austria most parts of the densely populated lower elevation areas in the western part have radiation levels above $1,150 \mathrm{kWh} / \mathrm{m}^{2} /$ year [82]. The areas with the highest irradiance are located in the south with an irradiance above $1,250 \mathrm{kWh} / \mathrm{m}^{2} /$ year. Typical DNI levels in lower elevation areas are in the range between 1,000 and $1,200 \mathrm{kWh} / \mathrm{m}^{2} /$ year.
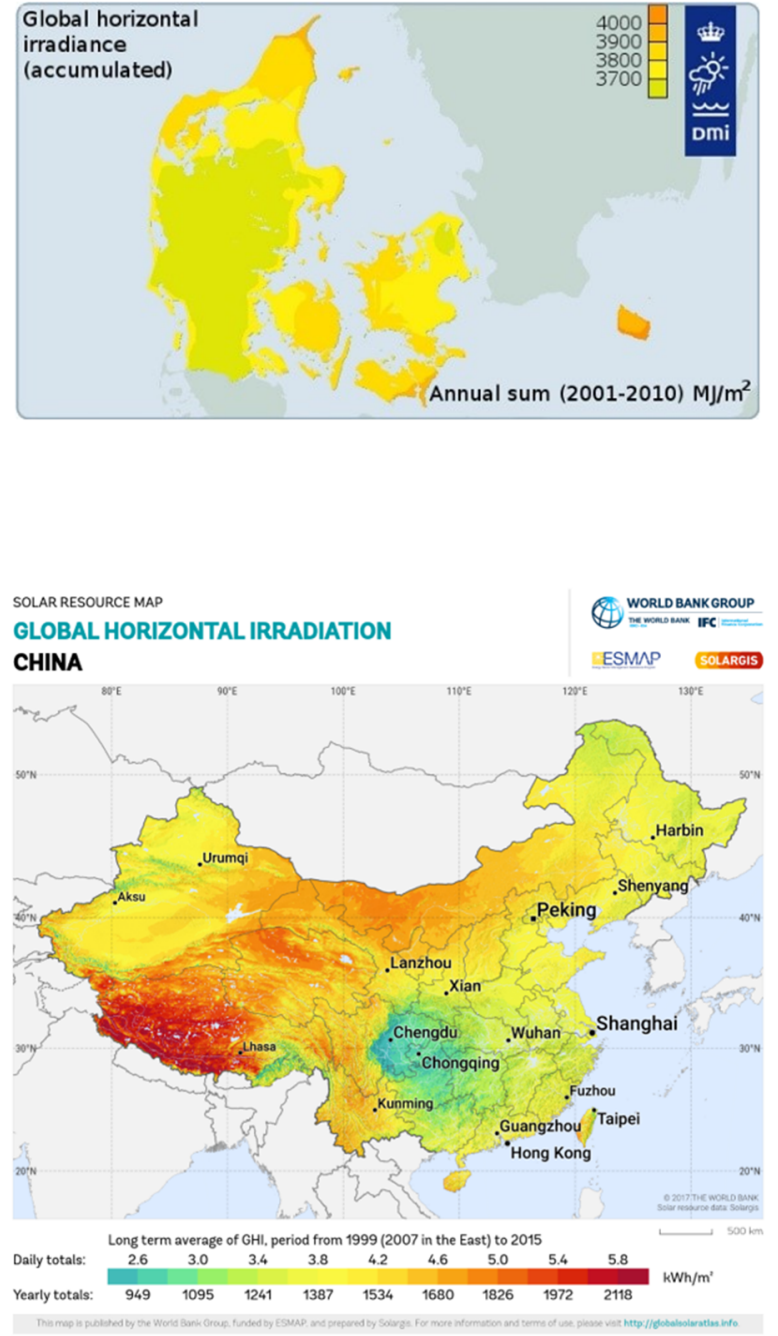

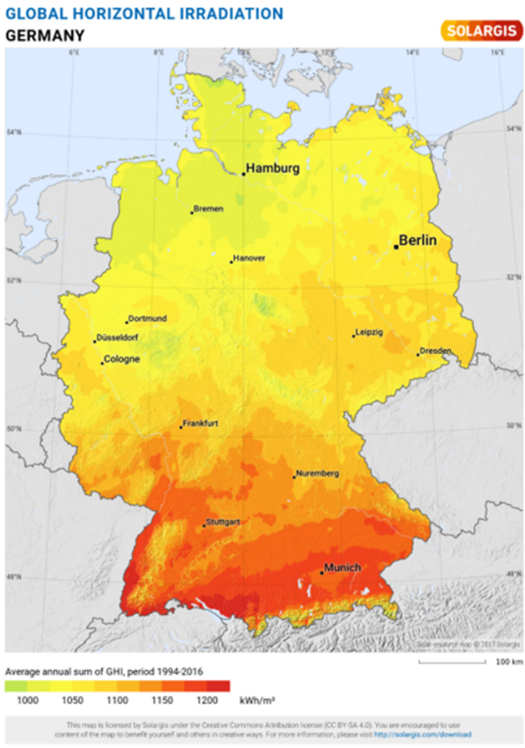

GLOBAL HORIZONTAL IRRADIATION AUSTRIA

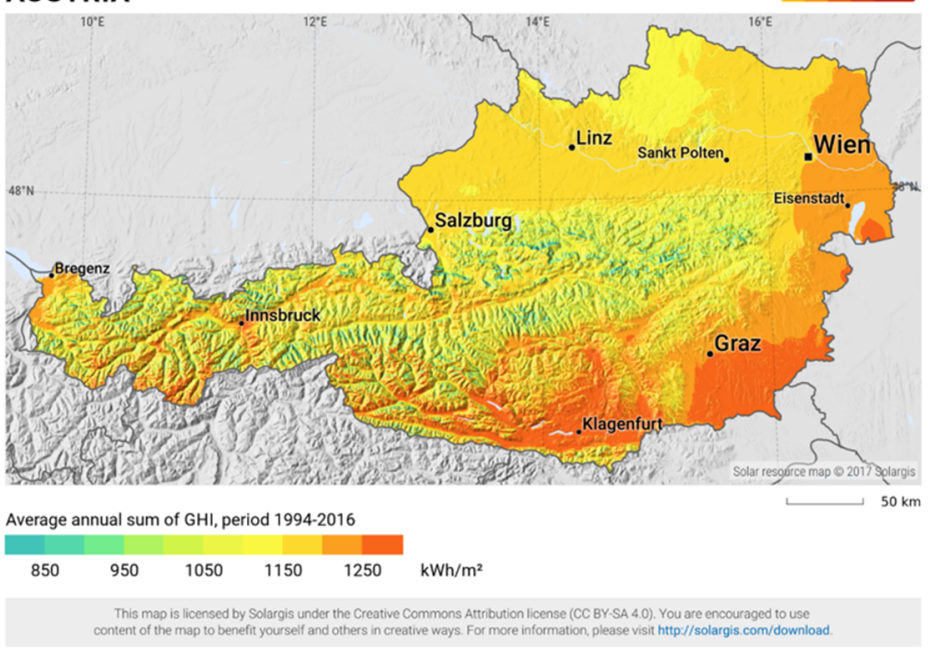

Fig. 2. Global irradiance in Denmark, Germany, China (mainland) and Austria; note that color scales differ among countries (source: Denmark [76], other: Solargis). 
Long-term average ambient temperatures in major cities are around $10{ }^{\circ} \mathrm{C}$ [83].

\subsection{Heat demand and heat supply infrastructure}

Denmark has very favorable conditions for solar thermal integration into DH networks. The country has a long-standing tradition in DH. A total of $63 \%$ of Danish households are connected to DH networks [57]. Almost $70 \%$ of the DH supply is provided by CHP plants. Denmark has also a relatively high summer load [84]. Typical supply/return temperatures of DH networks are $75 / 35-40{ }^{\circ} \mathrm{C}$ [23]. DH networks include both $\mathrm{SH}$ and DHW. Initiatives to reduce individual heating are also favorable for the development of DH. A ban on the installation of oiland gas-fired boilers in new buildings was put in place in 2013, and since 2016 the installation of oil-fired boilers is prohibited in existing buildings [57]. Danish researchers also proposed low temperature 4th generation DH networks in Denmark [85]. Lower DH network temperatures of $55 / 25{ }^{\circ} \mathrm{C}$ could significantly decrease the operating temperatures of the solar collector circuit and increase the thermal performance of FPCs in 4th generation DH networks.

The Chinese DH networks currently cover around 8.5 billion $\mathrm{m}^{2}$ of building floor area (building floor area is the typical unit of measurement), having nearly tripled since 2005 [86]. As urbanization continues, the building floor area in China is projected to increase by $40 \%$ by 2050 , reaching more than 80 billion $\mathrm{m}^{2}$ from 57 billion $\mathrm{m}^{2}$ today. The total building floor area covered by DH networks in Northern China tripled over the last decade, increasing nearly as much as the combined floor area growth in the northern urban heating (NUH) area (north part of China) since 2005. Solar thermal systems face extremely favorable natural conditions in these areas due to high heat demand and high solar irradiance.

A characteristic of Chinese DH networks is that they often provide heat only for space heating. DHW systems are separate and not fed by the grid [87]. Space heating systems in most places in Northern China are only put into operation for several months in winter heating seasons. For instance, the operation period of space heating systems in Beijing is November 15 to March 15 next year (4 months). There is no space heating supply in the rest of the year. Typical supply/return temperatures of new DH networks (radiator heating) in China are 75/ $50{ }^{\circ} \mathrm{C}$ or $85 / 60{ }^{\circ} \mathrm{C}$. For the floor radiant heating systems, typical supply/ return temperatures are $35 / 30{ }^{\circ} \mathrm{C}$ or $45 / 40{ }^{\circ} \mathrm{C}$ [88].

Only $1 \%$ of the DH supply in China is currently covered by renewable energies [86]. More than $80 \%$ of space heating in Northern China are supplied by coal boilers, which is a main reason for the air pollution in winter. China has a great need to lower the environmental footprint of its $\mathrm{DH}$ networks and the country has pursued assertive public policy decisions in recent years towards cleaner and energy-efficient $\mathrm{DH}$.

In Germany, the final energy consumption was 2,542 TWh in 2016 with more than $50 \%$ used for heating applications [89]. Renewable energy technologies are supplying a growing part of the heat consumption. In 2016, the share of renewable heat amounted to 164 TWh ( $13 \%$ of the heat consumption). Solar thermal plants contribute to around $5 \%$ of the renewable heat consumption and to around $0.6 \%$ of the total heat consumption [90]. The share of households connected to DH networks was $14 \%$ in 2016 (5.8 million households) with a heat consumption of 49 TWh. Almost the same heat quantity is used in industrial applications (48 TWh) and an additional 22 TWh by other consumers [91]. The heat production is mainly provided by CHP plants from gas (41\%) and coal (29\%). About $14 \%$ of the heat in DH was produced with renewable energies, mainly from biomass and renewable waste heat [91]. As there are no country-wide statistics about all DH networks available, it is likely that a lot of smaller systems are not included. For SDH systems, typical values for supply/return temperatures of DH networks are $70-110{ }^{\circ} \mathrm{C} / 40-80{ }^{\circ} \mathrm{C}$.

The Austrian final energy consumption amounted to 161 TWh in
2016, with a share of $52 \%$ attributed to heat [92]. In the same year, the energy fed into DH networks was 24 TWh. The heat supply to DH networks is provided with CHP (58\%) and heating plants (42\%) [93]. The predominant fuel for heating plants is biomass with a share of $61.4 \%$ [93]. The use of renewables (solar thermal, heat pumps, geothermal) within DH networks amounts to $1.72 \%$ [93]. Separate data for the solar thermal share is not available. Typical supply/return temperatures of DH networks are in the range of 75-95/55-65 ${ }^{\circ} \mathrm{C}$ and can reach $90-145^{\circ} \mathrm{C}$ in the transport pipes during the heating season [15]. The high supply temperatures in winter restricts direct solar thermal supply to the summer months and sets limits to the solar fraction at which a solar thermal installation can be operated economically.

\subsection{Energy prices of competing technologies}

The market potential of large-scale solar thermal systems depends on the availability, price and environmental impact of competing technologies and heat sources. Coal, natural gas and oil are the prevailing fossil fuels in DH networks and industrial processes both worldwide and in Denmark, China, Germany and Austria [94]. The major renewable heat sources in future $\mathrm{DH}$ networks besides solar thermal are biomass, geothermal, waste heat from industrial processes and waste-to-energy [95]. If a large amount of waste or excess heat is available, solar thermal heat supply usually becomes less of a viable option [18]. Biomass is typically both a competing and complementing heat supply option. Combined solar thermal-biomass systems, where the solar thermal systems cover the main share of the summer load (especially reducing partial load operation) and biomass provides an auxiliary fuel during the winter months, offers advantages for both technologies [96].

Natural gas plays a significant role in the European short and medium term transformation strategy towards sustainability, as the $\mathrm{CO}_{2}$ emissions are lower than for other fossil fuels [97]. Current large-scale solar thermal projects, like the world's largest solar thermal system currently in the concept phase, usually use costs from heat supply with gas boilers as the reference scenario [98]. Prices of natural gas in Denmark, Germany and Austria before tax have been stable and on comparable levels over recent years. After tax, prices differ significantly between Denmark (71.2 €/MWh on average between 2010 and 2018), Germany (37.7 €/MWh) and Austria (39.6 €/MWh). As the fuel constitutes the principal cost component of heat supply by natural gas boilers [99] and efficiencies are close to $100 \%$ [100], competitiveness of solar thermal systems with natural gas boilers implies prices in the range of around $70-80 € / \mathrm{MWh}$ in Denmark and $30-40 € / \mathrm{MWh}$ in Germany and Austria. Taxes on fossil fuels for heating purposes in Denmark are among the highest in Europe, with significantly lower taxes for industrial applications (with the exception of coal) and zero tax on biomass [101].

Prices for heat provided by biomass depend a lot on the location of the heating plant, because a major portion of market activity remains on a regional level within a country [102]. A recent study on Austrian biomass heating plants based on 20 case studies shows LCOH of 69 to $106 € /$ MWh with an average of $84 € /$ MWh (before tax) [103].

In China, the energy sector is heavily regulated. The main policy maker is the National Development and Reform Commission (NDRC) alongside the central government pricing authority and provincial/ local government pricing agencies. Reforms towards a greater market system are under way in various sectors, such as natural gas [104] or electricity [105]. Energy prices can vary greatly by region, e.g. up to $52 \%$ for the non-residential natural gas price [106]. The typical price of electricity in China is $69 € / \mathrm{MWh}$ including tax (for district networks). The price of natural gas in China is $35 € /$ MWh for heat supply by DH networks. 


\subsection{Promotion schemes}

The Danish government introduced investment subsidies during the 1990s to support CHP plants, renewable energy generation and energy efficiency measures. Most of these grants are no longer available for new DH investments. However, decentralized CHP plants operating in the electricity market receive a premium tariff (the so-called capacity credit) on top of the market price plus an electricity production subsidy (for gas and waste-fueled plants) or a surcharge (for biomass or biogasfueled plants). Since the end of 2018, this premium is only available for CHP plants using renewable energies [57].

An indirect incentive to the Danish SDH development is the requirement for all DH utilities to obtain a certain amount of energy savings each year. If a utility cannot reach the required savings, it has to buy credits from another utility, which has a surplus of "energy saving points", because it was able to exceed its energy saving target [107]. The credits are quoted on a stock market on their own, similar to the carbon emissions trading system, thus varying in price per MWh of saved heat. The average market price between 2012 and 2014 was in the range of 40 to $50 € / \mathrm{MWh}$ [14]. Former agreements between the Danish Energy Agency and the energy distributors which allowed collector arrays connected to DH networks to be part of this market counted the first year of solar heat production as energy savings, thus creating a surplus of valuable credits for the utility, which could pay back part of the investment. By the end of 2016, an agreement expired and was not renewed. This situation led many DH utilities to refrain from investing in new solar thermal systems, waiting to see how the situation would develop. This was a major reason for the sharp market decline in 2017 and 2018 (see Section 4.1). In 2019, a new agreement was reached [108], which is expected to help the market to recover.

The Chinese central government set up the "Clean Heating Initiative" for the period 2017-2021 to control air pollution. By the end of 2021, the percentage of coal boilers should be reduced by more than $50 \%$. The authority supports the exchange of oil boilers with renewable energy for space heating, including solar thermal energy. In rural areas, oftentimes there are no heating devices. The Green Energy Revolution is one of the main steps to achieve rural revitalization under the policy of the roadmap for rural vitalization ("No 1 central document" of 2018). Rural areas have very cheap land, which may be an emerging market for solar space heating in the near future. In addition, some flagship local governments, like Shandong and Hebei, have their own subsidy programs to promote large-scale solar thermal systems. Based on the national solar energy development plan (2015-2020), the number of large SDH plants should reach more than 200 and the total installed collector area for SDH plants should reach more than 4 million $\mathrm{m}^{2}$ by the end of 2020 [66].

Germany's transformation strategy to renewable energies ("Energiewende") targets a share of renewable energies of the final energy consumption of at least $18 \%$ in 2020 and 30\% in 2030 [109]. In the heating sector, final energy consumption is to be reduced by $20 \%$ and the heat from renewable energies is to be increased to $14 \%$ until 2020. To reach these shares, one possible scenario "Erneuerbare Energien" aims to increase the heat supply by DH networks to 75 TWh/a in 2050. Meanwhile, the contribution from solar thermal energy to the final energy consumption should increase from 3 TWh/a in 2008 to 80 TWh/a [110].

In 2009, an incentive scheme ("Marktanreizprogramm") was put in place for solar thermal systems [111]. Solar thermal plants with collector areas larger than $20 \mathrm{~m}^{2}$ receive a subsidy of up to $50 \%$ of the investment costs. Plants larger than $40 \mathrm{~m}^{2}$ feeding into $\mathrm{DH}$ networks receive up to $40 \%$ of the investment costs. Alternatively, a performance-based incentive can be chosen, where a rate of $0.45 € / \mathrm{kWh}$ of the yearly collector yield (according to the Solar Keymark certificate) is paid once. The subsidy is limited to $45-65 \%$ of the total investment cost. Additionally, incentives for $\mathrm{DH}$ networks and heat storages are paid. Since 2009, active market development is done by Solites together with the German district heating association AGFW and other partners in international SDH projects as well as in the German projects SolnetBW I and II and Solnet 4.0 [55]. In July 2017, the German Ministry for Economic Affairs and Energy has established a new subsidy scheme for feasibility studies and realization of innovative "District Heating Pilot Projects 4.0" ("Wärmenetze 4.0"), which supply at least 50\% of their annual heat consumption from renewable energy sources or industrial waste heat and have a maximum supply temperature of $95{ }^{\circ} \mathrm{C}$ [112]. For solar process heat applications, a new promotion scheme has been established in March 2019, which subsidises up to 50\% of the additional investment cost of a solar thermal installation with a maximum amount of 5 million EUR per project [113].

In the framework of the EU agreement on the climate-energy package, Austria committed to increase the share of renewable energies to $34 \%$ of the national energy mix by 2020 [114]. As part of a large strategy to promote the use of solar thermal energy, a special program was designed to promote large-scale solar thermal installations in 2010 [115]. Installations with a collector area of 100 to $10,000 \mathrm{~m}^{2}\left(2000 \mathrm{~m}^{2}\right.$ until 2015) are eligible. The funding is based on the additional investment costs for the solar thermal system (including piping, storage, system integration) compared to a fossil fuel reference system. The funding percentage is $40 \%$ ( $>2000 \mathrm{~m}^{2}: 30 \%,>5000 \mathrm{~m}^{2}: 20 \%$; $+5 \%$ for small and medium enterprises) with a limitation of 750,000 EUR per project. A combination with other funding programs is possible. An accompanying research program has been established to systematically evaluate optimization and technology development potentials [116].

\subsection{Business models and regulations}

DH in Denmark is mainly regulated by the Heat Supply Act since its publication in 1979. The idea of this regulation is that end-users can benefit from DH. All DH utilities which follow the Heat Supply Act are non-profit. Consequently, 99\% of Danish DH companies are owned and controlled by the consumers. The non-profit orientation allows DH utilities to have a long-term investment horizon, which is favorable for the capital intensive solar thermal technology. DH utilities usually provide the investment in new solar thermal systems, take on the financial risk and operate solar thermal plants themselves. Oftentimes, the municipality guarantees on loans, which allows utilities to get good financing conditions. As large-scale solar thermal systems are widespread in Denmark and system concepts are highly standardized, district utilities have gained trust and experience with the technology. Turn-key suppliers further help to minimize the technological risk [117].

In China, large-scale solar thermal systems for space heating and industry process heat just started in recent years. Projects mainly rely on subsidies from the government at the current stage. For example, the Langkazi Tibet Solar Heating project (see Section 6.2) is 100\% subsidized by the central government.

In Germany, solar thermal projects are often realized in bioenergy villages ("Bioenergiedorf"), see Section 6.3 for a best practice example. Bioenergy villages cover the main share of their energy demand from local renewable energies. The projects are usually initiated by citizens, who cooperate with the municipality, local craftsmen, building companies and consulting engineers. Oftentimes, the citizens set up a registered cooperative to manage the energy supply and distribution, which has the aim of long-term favorable prices instead of short-term profit maximization. Furthermore, it allows a high degree of co-determination and limited liability risks. For the heat supply, wood chip boilers and solar thermal plants can be used to supply heat to the DH network [118].

Another typical business strategy for large-scale solar thermal systems in Germany is the change from fossil fuels to renewable energies in $\mathrm{DH}$ systems. One regulatory reason for this effort is the reduction of the primary energy factor of the $\mathrm{DH}$ network. With a reduced primary energy factor new customers meet the legal requirements for using 
renewable energies in new buildings by connecting to the DH network [119]. Furthermore, DH companies as well as industries benefit from long-term cost stability of solar heat.

In Austria, the ESCo business model (also known as Solar Contracting) has become widespread for large-scale solar thermal systems. To overcome the burden of high investment cost and perceived uncertainty connected to solar heating, the ESCo takes responsibility for the investment, design and operation of the plant and sells the heat to housing facility owners and/or DH utilities, which pays a contracted price. All risks are mitigated to the ESCo. The Austrian company S.O.L.I.D. is the main driver behind solar ESCo and was able to realize, among others, four large plants feeding into the DH network of Graz [19].

\section{Best practice examples}

The best practice examples show typical system concepts, while at the same time highlighting the diversity of applications. Best practice examples were chosen based on numerous scientific research projects for system evaluation and performance analysis conducted by DTU for Denmark [60], Solites for Germany [55] and AEE INTEC for Austria [120]. The best practice example for China was built in collaboration with the leading Danish turn-key supplier Arcon-Sunmark A/S. The large-scale solar thermal systems Dronninglund SDH in Denmark, Langkazi Tibet Solar Heating in China, Bioenergy Village Büsingen SDH in Germany and Salzburg Lehen in Austria are introduced in this chapter. The basic plant data are listed in Table 3.

\subsection{Dronninglund SDH (Denmark)}

Dronninglund Fjernvarme is a consumer-owned cooperative, which supplies around 1,350 consumers with a $46 \mathrm{~km}$ DH network (2016). In 1989, Dronninglund Fjernvarme became the first Danish DH company to install natural gas-driven engines for CHP production. In 2005, the board and general assembly of Dronninglund Fjernvarme realized that they should replace natural gas with renewable energies. In 2007, Nordjyllands Vækstforum subsidized a pre-feasibility study, which showed that a large-scale solar thermal system with seasonal heat storage could cover up to $50 \%$ of the heat demand. Furthermore, the heat production price would not be increased for the consumers in case of a subsidized investment [9].

The aim of the project was to prove the feasibility of heat supply for DH networks with large-scale solar thermal plants and PTES. Furthermore, the utilization of PTES to store excess heat from waste incineration, industries and CHP production is analyzed. The plant started to operate in May 2014 (Fig. 3).

A simplified hydraulic scheme of the plant is shown in Fig. 4. The collector aperture area is $37,573 \mathrm{~m}^{2}$ (2,982 solar panels). The tilt of the solar collectors is $35^{\circ}$ to maximize the annual solar yield. Each row of the collector array has 21 solar collectors connected in series. This is a typical number for collector arrays with harp-type collectors as in Dronninglund, as the pressure drop becomes too high or the flow velocity becomes too small in the manifold pipes if more collectors are connected in series. Inlet temperatures of the collector array are around $40{ }^{\circ} \mathrm{C}$ in summer and can drop to around $15-20{ }^{\circ} \mathrm{C}$ in winter. Outlet temperatures reach $80-90{ }^{\circ} \mathrm{C}$ in summer and typically $30-40{ }^{\circ} \mathrm{C}$ in winter.

The seasonal pit thermal energy storage with a volume of $62,000 \mathrm{~m}^{3}$ was built in an abandoned gravel pit. The ground water level is approximately $3 \mathrm{~m}$ below the bottom of the storage and the soil consists of gravel and sand. The storage is insulated at the top with a floating cover. Insulation for the area which separates the water from the

Table 3

Basic plant data of best practice examples.

\begin{tabular}{|c|c|c|c|c|c|}
\hline Plant & & Dronninglund SDH (DK) & $\begin{array}{l}\text { Langkazi Tibet Solar Heating } \\
(\mathrm{CN})\end{array}$ & $\begin{array}{l}\text { Bioenergy Village Büsingen SDH } \\
\text { (GER) }\end{array}$ & Salzburg Lehen (AT) \\
\hline Latitude & [deg] & $57.2 \mathrm{~N}$ & $28.9 \mathrm{~N}$ & $47.7 \mathrm{~N}$ & $47.8 \mathrm{~N}$ \\
\hline Longitude & [deg] & $10.3 \mathrm{E}$ & $90.3 \mathrm{E}$ & $8.7 \mathrm{E}$ & $13.0 \mathrm{E}$ \\
\hline Global irradiance (TRY) & {$\left[\mathrm{kWh} / \mathrm{m}^{2} / \mathrm{y}\right]$} & 1030 & 2110 & 1100 & 1090 \\
\hline Operation start & {$[y]$} & 2014 & 2018 & 2013 & 2016 \\
\hline Life time & {$[y]$} & 30 & 20 & 25 & 25 \\
\hline \multicolumn{6}{|l|}{ Application } \\
\hline Type & & SH, DHW & SH & SH, DHW & SH, DHW \\
\hline \multicolumn{6}{|c|}{ Supply/return temperature of connected } \\
\hline (district) heating network & {$\left[{ }^{\circ} \mathrm{C}\right]$} & $75 / 40$ & $65 / 35$ & $80 / 50$ & $65 / 35-45$ \\
\hline \multicolumn{6}{|l|}{ Collector array } \\
\hline Collector type & & FPC (glass and foil) & FPC (glass and foil) & ETC with CPC & FPC (single glazed) \\
\hline Aperture area & {$\left[\mathrm{m}^{2}\right]$} & 37,573 & 22,275 & 993 & 1,858 \\
\hline Slope (inclination) & [deg] & 35 & 40 & 30 & 45 \\
\hline Orientation & [deg] & 180 (south) & 180 (south) & 180 (south), 175, 148 & 180 (south) \\
\hline Land area & {$\left[\mathrm{m}^{2}\right]$} & 130,000 & $\mathrm{n} / \mathrm{a}$ & $\mathrm{n} / \mathrm{a}$ & roof-mounted \\
\hline \multicolumn{6}{|l|}{ Storage } \\
\hline Diurnal heat storage (size, & ype) & $865 \mathrm{~m}^{3}$ steel & $15,000 \mathrm{~m}^{3}$ pit & $100 \mathrm{~m}^{3}$ steel & $200 \mathrm{~m}^{3}$ steel \\
\hline Seasonal heat storage (size & type) & $62,000 \mathrm{~m}^{3}$ pit & none & none & none \\
\hline \multicolumn{6}{|l|}{ Additional heat sources } \\
\hline \multirow[t]{4}{*}{ Type, capacity } & & CHP natural gas (6.4 MWth) & 2 electric boilers ( $3.0 \mathrm{MW}$ ) & 2 wood chip boilers & $\mathrm{DH}$ \\
\hline & & 2 bio-oil boilers (15 MW) & & $(1,350 \mathrm{~kW})$ & \\
\hline & & natural gas boiler (8 MW) & & oil boiler & $(1.8 \mathrm{MW})$ \\
\hline & & absorption heat pump (4.7 MWth) & & $(730 \mathrm{~kW})$ & $\begin{array}{l}\text { heat pump } \\
(160 \mathrm{~kW})\end{array}$ \\
\hline \multicolumn{6}{|l|}{ Performance } \\
\hline Measurement period & & 2018 & $\mathrm{n} / \mathrm{a}$ (simulated values) & 2015 & $08 / 2013-07 / 2014$ \\
\hline Irradiance collector plane & {$\left[\mathrm{kWh} / \mathrm{m}^{2} / \mathrm{y}\right]$} & 1,244 & 2,300 & 1,396 & 1,359 \\
\hline Heat demand & {$[M W h / y]$} & 35,726 & 16,769 & 4,469 & 3,388 \\
\hline Solar yield & {$\left[\mathrm{kWh} / \mathrm{m}^{2} / \mathrm{y}\right]$} & 493 & 966 & 603 & 533 \\
\hline Solar fraction & [\%] & $52 \%$ & $100 \%$ & $13 \%$ & $29 \%$ \\
\hline Utilization ratio & [\%] & $40 \%$ & $42 \%$ & $40 \%$ & $39 \%$ \\
\hline
\end{tabular}

Source: PlanEnergi (DK), Sunrain (CN). 

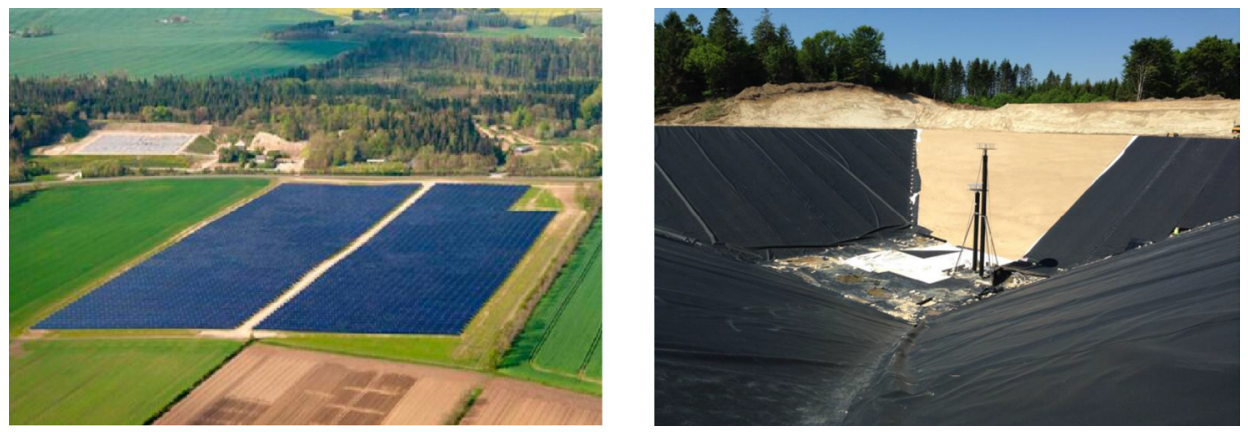

Fig. 3. Collector arrays (left) and PTES (right) of Dronninglund SDH (source: PlanEnergi).

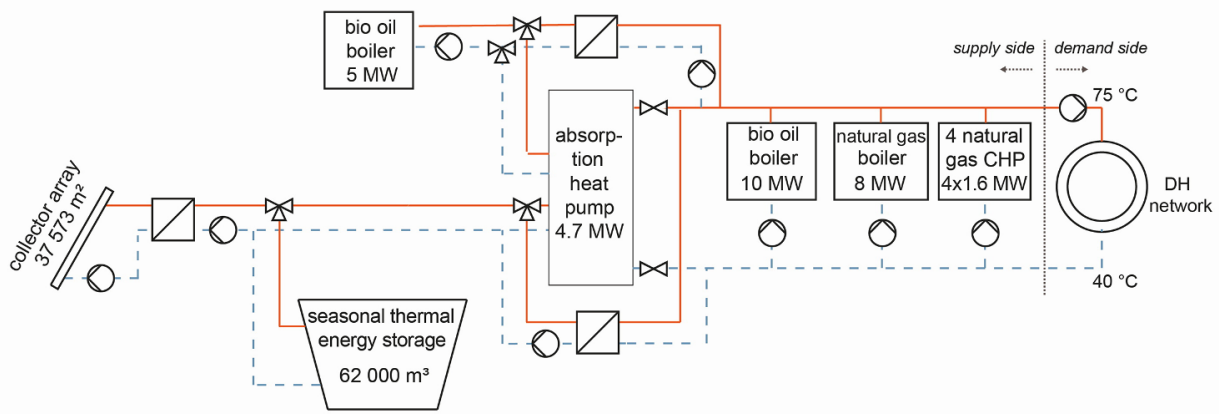

Fig. 4. Hydraulic layout (simplified) of Dronninglund SDH. Pumps indicate flow direction in inlet/return pipes with lower temperatures (blue dashed lines) and outlet/supply pipes with higher temperatures (red solid lines) (source: Solites).

ground is economically not feasible. In summer (non-heating season), the solar thermal energy supply exceeds the heat demand of the connected consumers in Dronninglund by far (Fig. 5). The surplus solar heat is used to heat up (charge) the PTES to a maximum temperature of $90{ }^{\circ} \mathrm{C}$. The maximum temperature of the storage is determined by the maximum tolerance temperature and lifetime of the liner material. In autumn (heating season), hot water of the upper part of the storage is delivered to the DH network, while the cooler DH return flow enters the bottom part of the PTES with a temperature of around $40{ }^{\circ} \mathrm{C}$ (discharging). If the temperature in the upper part of the PTES is lower than the required DH supply temperature, the missing energy may be provided by the absorption heat pump with superheated hot water $\left(160{ }^{\circ} \mathrm{C}\right)$, driven by the bio-oil boiler.

The storage can be cooled down from $40{ }^{\circ} \mathrm{C}$ to $10{ }^{\circ} \mathrm{C}$ (about $30 \mathrm{~K}$ below the return temperature of the $\mathrm{DH}$ network) by using the storage as a heat source for the absorption heat pump. This has several positive effects on the system efficiency. First, the storage capacity is increased, i.e. with the same storage volume more energy can be stored (higher temperature difference) and the storage can contain more heat in the next summer. Second, the average storage temperature is decreased, which reduces storage losses. Third, the efficiency of the solar thermal collectors is increased due to lower operating temperatures. In spring, autumn and winter, the bio-oil boilers and four gas engines cover the major part of the heat load, which is the conventional DH supply mode. In the measurement period, the solar fraction was $52 \%$ (Fig. 5) [121].

Dronninglund SDH was financed by an EUDP (Energy Technology Development and Demonstration Programme) project supported by the Danish Energy Agency. The subsidy was granted for detailed design and for investments in PTES, piping, heat exchangers and a control system to connect the production units. The subsidy of 21 million DKK (2.8 million EUR) amounts to around $20 \%$ of the total system cost. The specific costs were around $389 € / \mathrm{m}^{2}$ collector aperture area. The heat price (before subsidies) is $50 € / \mathrm{MWh}$, which is slightly higher than typical SDH plants in Denmark due to the seasonal heat storage, high solar fraction and an advanced system concept with multiple heat supply sources.

\subsection{Langkazi Tibet Solar Heating (China)}

Tibet has the most abundant solar energy resources in the world, with the yearly global radiation on the horizontal surface exceeding $2000 \mathrm{kWh} / \mathrm{m}^{2} /$ year. Conventional energy infrastructures, such as natural gas pipelines, are very expensive. The Chinese central government attaches much importance to standard of living improvements in Tibet and has allocated funds to build heating facilities for Tibetan people. Langkazi Town is located in a severe-cold and high-altitude area, where

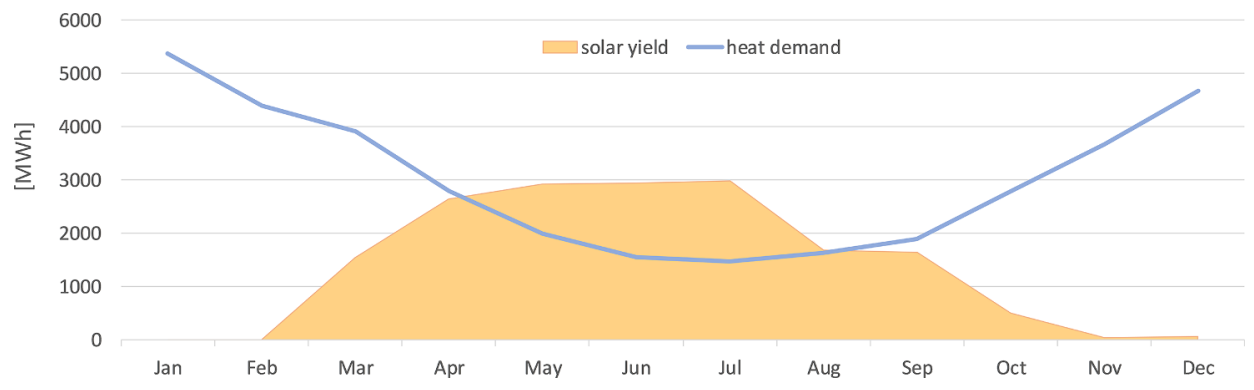

Fig. 5. Monthly solar yield and heat demand of Dronninglund SDH (data: Solites). 
heating is greatly needed. The elevation is $4,200 \mathrm{~m}$ and the boiling temperature of water is $84{ }^{\circ} \mathrm{C}$. The central and local governments started to construct a large SDH plant in 2017 (Fig. 6). Before, there were no space heating systems installed in the buildings. The project aims to prove the reliability and applicability of the deployed system concept and to provide a best practice example to solve the heating problems in Tibetan urban areas.

The project consists of a collector array, buffer storage, electric boilers, DH network and indoor heating terminal units. The project, as shown in Fig. 7, is divided into two phases. In Fig. 6, the first phase with $22,275 \mathrm{~m}^{2}$ collector area is shown, which was finished in November 2018. The tilt of the solar collectors is $40^{\circ}$. The size of the water pit storage is $15,000 \mathrm{~m}^{3}$. The water pit storage is used as a short-term storage, not a seasonal storage, as storage losses would be too high for a cost-efficient seasonal storage at this elevation. The solar heat can be delivered directly to the DH network or the storage. The low supply/ return temperatures of $65 / 35{ }^{\circ} \mathrm{C}$ of the $\mathrm{DH}$ network are favorable for solar thermal heat supply. Two electrical boilers $(2 \times 1.5 \mathrm{MW})$ were installed as back-up heat sources. In the first phase, $82,600 \mathrm{~m}^{2}$ building floor area with 26 communities were connected to the DH network. In the second phase, $14,525 \mathrm{~m}^{2}$ collector area will be added, when more consumers will be connected to the DH network in the near future. The collector array is located around $2 \mathrm{~km}$ south of Langkazi Town.

Fig. 8 shows the calculated solar yield and heat demand. The designed heating period is from September 23 to May 31 (251 days in total). The outdoor design temperature during the heating period is $-14.4{ }^{\circ} \mathrm{C}$. The indoor design temperature is $18{ }^{\circ} \mathrm{C}$. The solar yield is higher in winter than in summer, because there is a lot of rain in summer and the irradiance is lower. The DH network provides only space heating and not DHW. As many DH networks in China, it is turned off during the summer months. In the future, DHW could be added to increase the summer load. The solar collector field aims to cover more than $90 \%$ of the heat demand.

Langkazi Tibet Solar Heating is a $100 \%$ subsidy project. The project received a grant of 175 million RMB from the central government. It was realized as a turn-key solution by a consortium of Beijing Heating Project Design Co. Ltd, Suneast Arcon-Sunmark and Sunrain Group. The project adopts the internationally advanced SDH technology of the Danish company Arcon-Sunmark A/S, that is responsible for the design and technical supervision of the collector array, storage and heat exchanger station. All critical equipment of the solar collector circuit was imported from Europe. The DH network and heating terminal units were designed by Beijing Heating Project Design Co. Ltd. The whole project is coordinated by Sunrain Group.

\subsection{Bioenergy Village Büsingen SDH (Germany)}

Büsingen is a German village, but forms a German exclave in Swiss territory, which leads to particular legal boundary conditions under Swiss economic law. The German renewable energy law is not valid and therefore a widespread solution for bioenergy villages using a biogas plant was not feasible. For this reason, Büsingen is the first German bioenergy village realized with SDH, providing heat for more than 100 houses by biomass boilers and a large-scale solar thermal plant. The plant is an important best practice example for bioenergy villages in Germany.

The main part of the collector array is installed ground-mounted on a simple foundation of rammed steel profiles with an inclination of $30^{\circ}$. To maximize the total collector area, a smaller part is installed on the front of the boiler house with an inclination of $60^{\circ}$ (Fig. 9). The collector area in combination with the inclination of the collectors was optimized for a high solar yield without too much stagnation in summer. A photovoltaic plant on the roof of the boiler house produces electricity for the operation of the plant.

The simplified hydraulic scheme of the plant is depicted in Fig. 10. All heat sources can feed in the buffer storage or directly to the DH network. For the heat supply in winter, two wood chip boilers are installed. Two buffer storages with a total storage volume of $100 \mathrm{~m}^{3}$ can buffer the produced heat up to a few days. If there is not enough solar heat in summer, the smaller wood chip boiler is operated and feeds the DH network and the storage. A short-term operation of the wood chip boilers is avoided in summer, because it would be uneconomic and produce higher emissions. Therefore, in summer the outlet temperature of the solar collector circuit is controlled by the frequency-controlled pumps to reach the supply temperature of the DH network to feed the heat directly to the network. In winter, the solar yield is maximized by allowing a lower outlet temperature using reheating with the wood chip boilers. The oil boiler is operated to cover the short-term heat demand in summer and serves as a back-up in case of failure and maintenance of the wood chip boilers [122]. The heat transfer medium both in the collector circuit and the DH network is water ("Aqua system" of Ritter XL Solar). The advantage of the "Aqua system" is that the number of technical devices, such as heat exchangers, can be kept as low as possible and the vulnerability of the overall system can be minimized.

The measured solar yield and heat demand for the year 2015 is shown in Fig. 11. In this year, the solar thermal heat supply covered the whole heat demand from the end of June until the middle of August. Because the heat transfer medium is water, frost protection is done by heating the solar collector circuit. These losses amounted to $4.8 \%$ of the solar yield [122].

Bioenergy Village Büsingen SDH plant was built by the regional energy supplier Solarcomplex AG, which aims to transform the energy supply of the Lake of Constance region to renewable energies by 2030 . One of the business models is to transform entire villages in BadenWürttemberg to bioenergy villages by building renewable DH networks for the heat supply and photovoltaic plants for the electricity supply. The inhabitants of the villages are involved in the projects from an early stage in order to achieve a strong commitment and high share of consumers connected to the renewable DH network. For the trend-setting showcase project Bioenergy Village Büsingen, Solarcomplex AG won
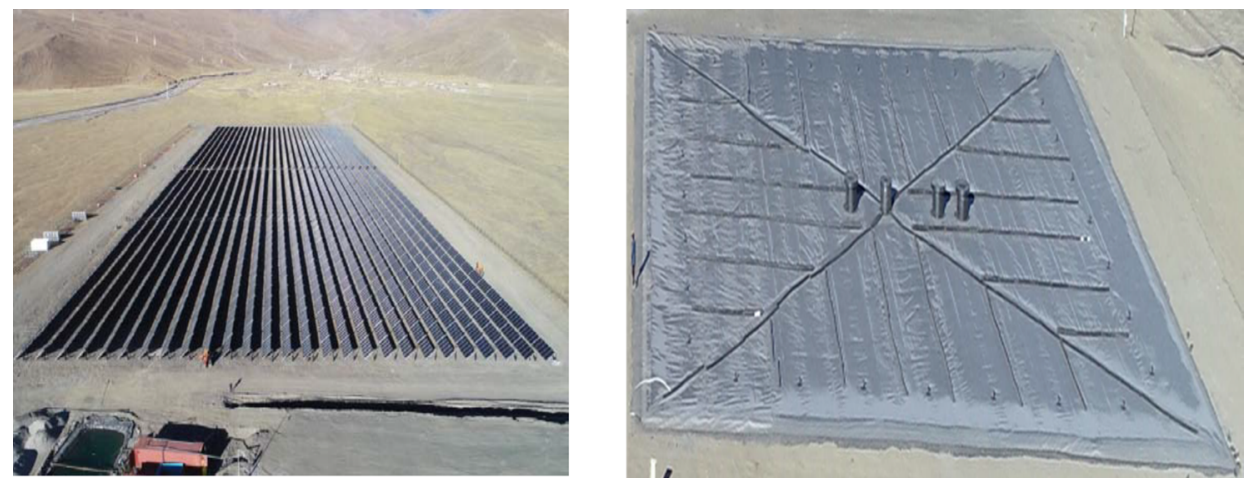

Fig. 6. Collector array (left) and PTES (right) of Langkazi Tibet Solar Heating (source: Sunrain). 


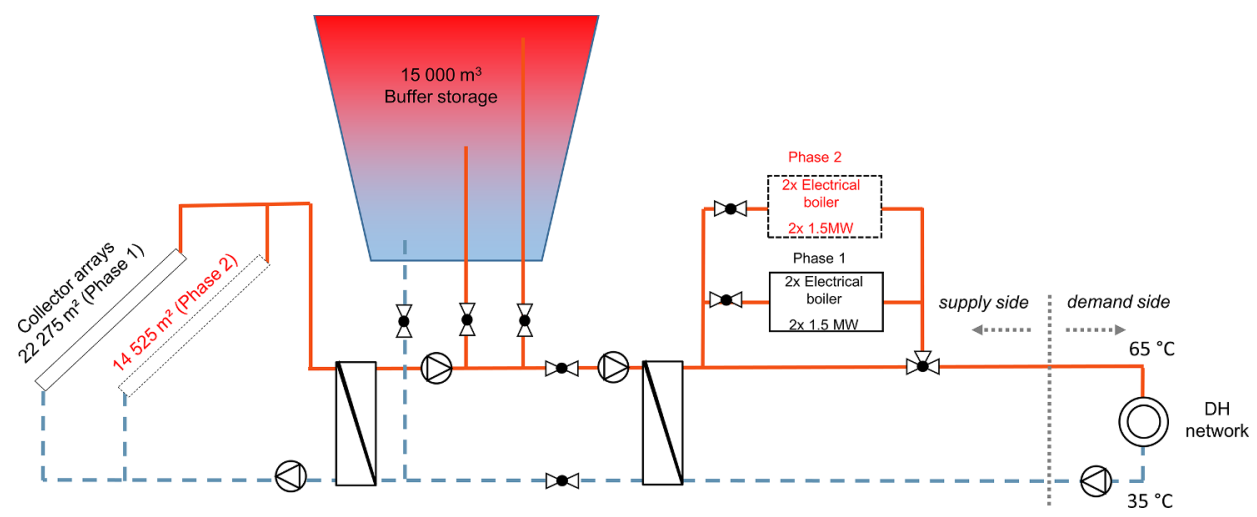

Fig. 7. Hydraulic layout (simplified) of Langkazi Tibet Solar Heating. Pumps indicate flow direction in inlet/return pipes with lower temperatures (blue dashed lines) and outlet/supply pipes with higher temperatures (red solid lines) (adapted from source: Sunrain).

the Georg Salvamoser prize 2014 and the Haus.Häuser.Quartiere prize in the category "Resource-Saving Urban Development". Because of the replacement of about 400,0001 of fossil oil per year through renewable energy sources, the purchasing power stays in the region. For all future DH projects, Solarcomplex AG decided to install large-scale solar thermal systems if there is no possibility to use industrial waste heat [123]. In 2018 alone, five new bioenergy villages with a similar concept to those in Büsingen went into operation.

\subsection{Salzburg Lehen (Austria)}

The plant Salzburg Lehen is a good example of how to integrate large-scale solar thermal systems with a high solar fraction into an urban environment. From 2011 to 2016, a new residential area was established in a former industrial zone in the city of Salzburg, as part of an urban development project (Fig. 12).

The residential area compromises of 287 newly built, low-energy apartments in multifamily buildings, commercial spaces and a renovated high-rise building with a total gross floor area of $48,860 \mathrm{~m}^{2}$ and total heat demand of $3,400 \mathrm{MWh}$ /year. All buildings are connected to a microgrid heating network with a supply/return temperature of $65 / 30^{\circ} \mathrm{C}$. In addition to the primary heat supply by the DH network of the city, a solar thermal plant, buffer storage and storage integrated compression heat pump were installed. The evaporation energy for the heat pump is solely provided by the solar thermal plant. Fig. 13 depicts the hydraulic layout of the plant.

The collectors are installed on the roofs of 13 buildings. The storage integrated heat pump increases the stratification of the storage by lifting the temperature in the top part of the storage (condenser side of the heat pump) and decreasing the temperatures at the bottom of the storage (evaporator side of the heat pump). For the collector array, this has two implications. First, the low temperatures at the bottom of the storage provide low inlet temperatures for the collectors. Second, the solar yield below the heat supply temperature of $65{ }^{\circ} \mathrm{C}$ can be utilized by lifting the temperature with the heat pump (condenser side).
The fact that the solar yield with low temperatures can be utilized is reflected in the control strategy, which is based on the temperatures at the bottom of the storage (and not, as usually, based on the temperatures of the middle or top layers). The solar collector circuit is operating, when the outlet temperature reaches a defined level above the temperatures of the bottom of the storage. The solar collector circuit has a fixed speed pump, which means that the temperatures of the outlet pipe of the solar collector circuit will vary depending on the operating conditions. The variable speed secondary pump regulates the flow temperature to the set point of $65{ }^{\circ} \mathrm{C}$. If this temperature cannot be reached, the pump runs at minimum speed. Furthermore, the plant has a night cooling mode for the storage, used as a stagnation prevention measure.

Monitoring data are available for a one-year period from August 2013 to July 2014 as part of a research project carried out by AEE INTEC [124]. The plant is dimensioned to cover most of the summer load, while avoiding overproduction (stagnation) during the summer months (Fig. 14). The collector tilt angle of $45^{\circ}$ is steeper than the tilt angle of $39^{\circ}$ which would maximize the total tilted solar irradiance on unshaded collectors for the location [125]. This design choice implies more yield in the winter months and less during the summer months, which reduces the risk of stagnation, but would not optimize the annual yield if the load would be sufficiently high in summer. The remarkably high yield of $533 \mathrm{kWh} / \mathrm{m}^{2} /$ year was facilitated by low collector operating temperatures and good storage management, with virtually no stagnation even in the summer months. The inlet temperatures of the solar collector circuit in summer were around $40{ }^{\circ} \mathrm{C}$, slightly above the return temperatures of the heating grid. In winter, the temperatures fell to around $15{ }^{\circ} \mathrm{C}$, well below the return temperatures of the heating network, due to the cooling down of the heat pump. The share of direct solar yield, i.e. the solar yield reaching an outlet temperature above $65{ }^{\circ} \mathrm{C}$, was $42 \%$ and the share of indirect solar yield was $58 \%$. Due to the storage integration, the heat pump could run at times when the solar plant was not operating, reaching more than 4,000 operating hours. The electricity consumption of the heat pump compressor was

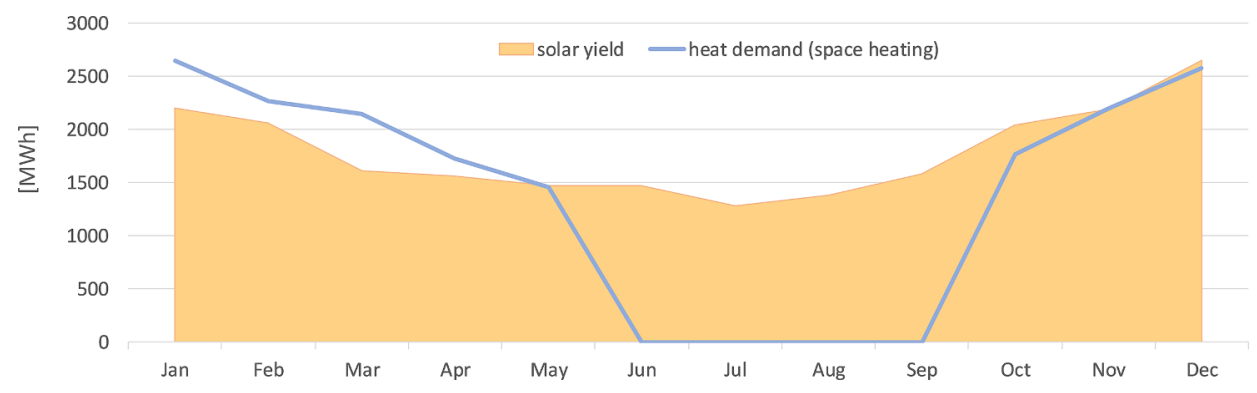

Fig. 8. Monthly solar yield and heat demand of Langkazi Tibet Solar Heating (calculated) (data: Sunrain). 


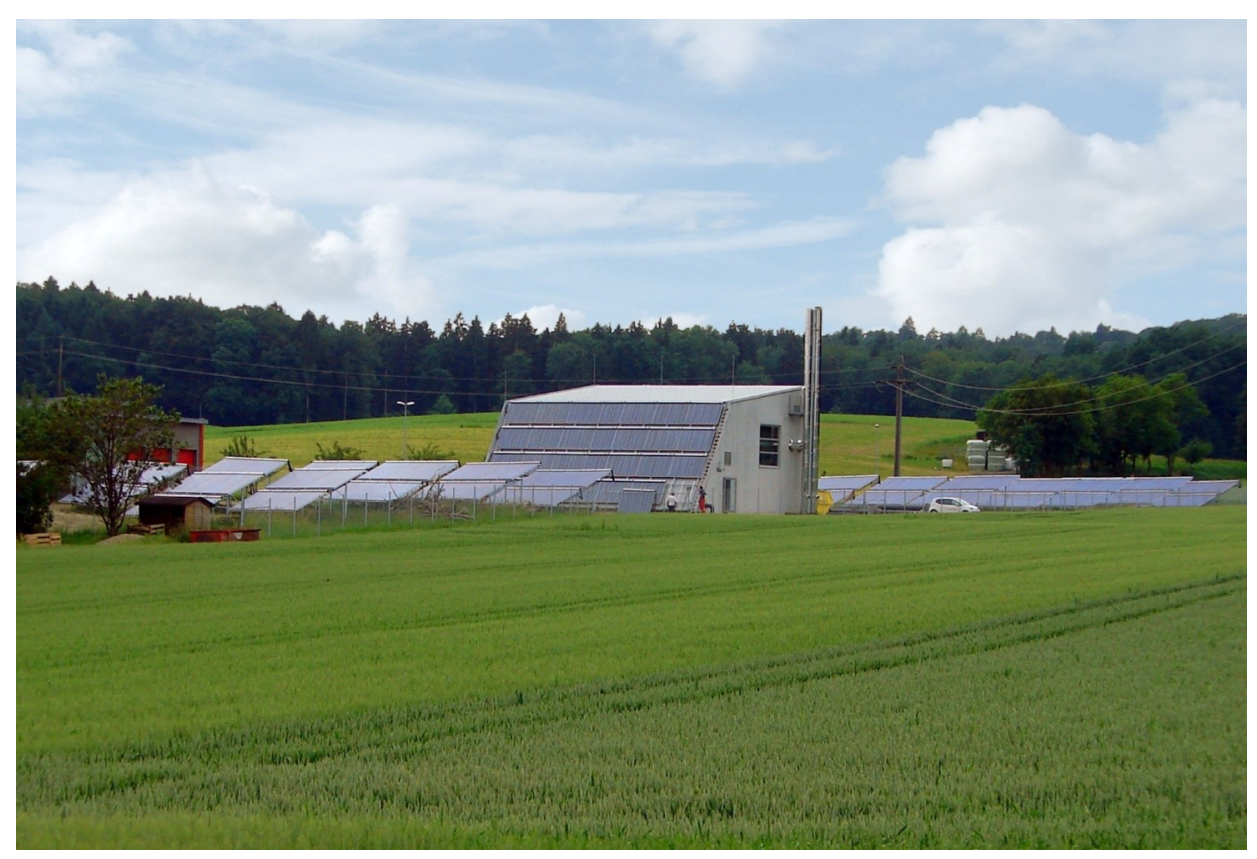

Fig. 9. Collector array and boiler house of Bioenergy Village Büsingen SDH (source: Solites).

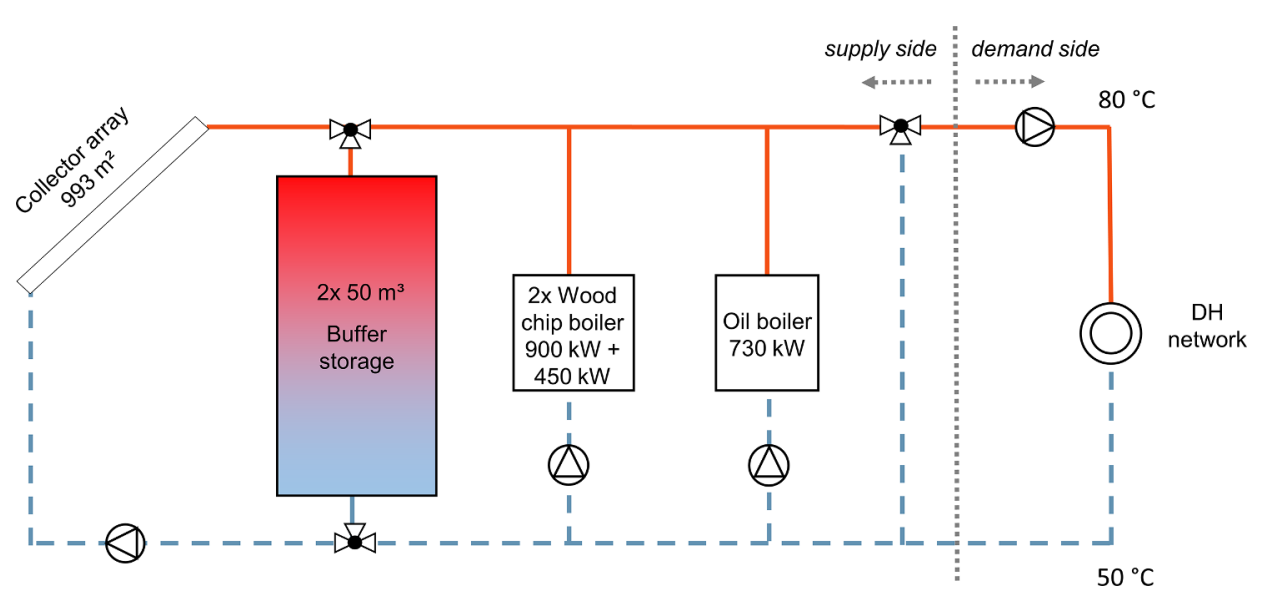

Fig. 10. Hydraulic layout (simplified) of Bioenergy Village Büsingen SDH. Pumps indicate flow direction in inlet/return pipes with lower temperatures (blue dashed lines) and outlet/supply pipes with higher temperatures (red solid lines) (source: Solites).

$163 \mathrm{MWh} /$ year or $16.4 \%$ of the solar yield. The heat pump had a Seasonal Performance Factor of 4.5. For a primary energy assessment of the whole system, the high solar yield needs to be weighed against the primary energy consumption of the heat pump, for which it is crucial if the electricity is from renewable sources. The storage integration also means that the electricity consumption of the heat pump can be directed to low electricity costs and surplus renewable electricity hours in the future.
The business model of the project is based on heat direct service (Wärme-Direkt-Service). The state-owned energy and infrastructure service provider Salzburg AG is responsible for the investment, operating and maintenance of the whole heating system including the distribution network. Heat customers pay a fixed amount per square meter gross floor area and variable cost per kWh of consumed energy, transferring the high initial investment of the solar thermal plant and the technical and financial risks to the energy service provider [34]. The

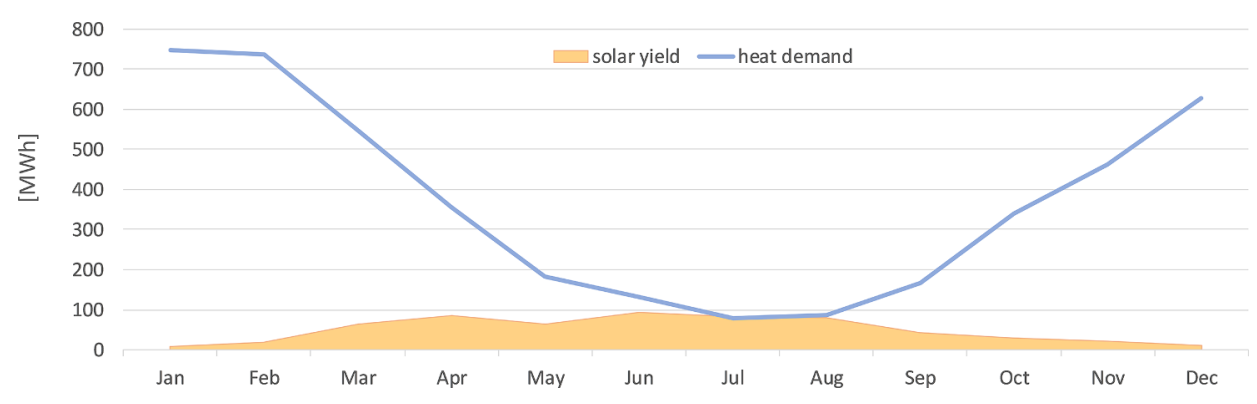

Fig. 11. Monthly solar yield and heat demand of Bioenergy Village Büsingen SDH (data: Solites). 


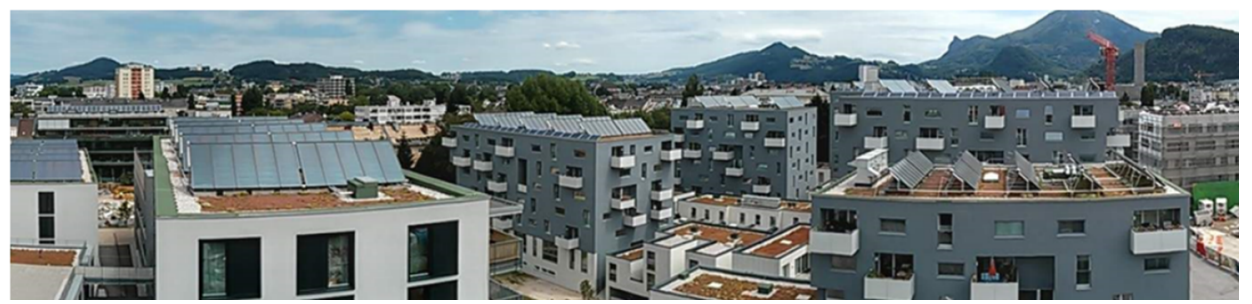

Fig. 12. Mounting of the collectors of Salzburg Lehen (source: AEE INTEC).

total investment of $900,000 €$ for the solar heating system was financed with combined subsidies of 400,000 €. Key success factors have been the appointment of a coordination body and the implementation quality assurance agreement between the involved parties [34].

\section{Discussion and future perspectives}

The leading role of Denmark in the deployment of large-scale solar thermal systems is due to a unique combination of favorable boundary conditions for SDH applications. Fig. 15 shows a comparison of Denmark, China, Germany and Austria along nine axes of the five boundary condition categories described in Chapter 5. Outer positions along an axis indicate better conditions for large-scale solar thermal systems.

Germany and Austria have similar boundary conditions and some overlap with China. The outstanding position of Denmark is shown in six areas:

- high market penetration of existing DH networks, especially for the heat supply of households

- high compatibility of solar thermal heat supply with DH load, i.e. high heat demand and heat density of existing DH networks, substantial summer load and availability of cheap land for groundmounted collectors near DH supply points

- low DH temperature levels

- high energy taxes on fossil fuels, which makes coal and natural gas fired CHP plants less profitable, while at the same time electricity selling prices for CHP plants are low

- availability of market-based subsidies for large-scale solar thermal systems as they are eligible for the national emissions trading system for energy distribution companies with subsidy rates based on the solar yield

- non-profit orientation, long-term investment horizon and availability of cheap loans for DH utilities

These favorable boundary conditions are combined with additional reinforcement success factors. Standardized, proven, low-cost system concepts and components from turn-key suppliers are both a factor and result of a thriving market as are positive experiences of DH utilities with solar thermal heat supply. Large-scale solar thermal systems in Denmark are on average bigger than in the other three countries and make better use of economies of scale.

In Denmark, incentives are clearly tailored to DH with no significant industrial and small-scale applications. Targeting DH utilities is a very effective strategy to promote large-scale solar thermal systems, as they make the investment decisions for new plants, have detailed knowledge of their networks and heat demand, are able to operate solar thermal systems alongside the DH network and can drive the market towards transparency on solar yields and installation costs. Furthermore, Danish DH utilities are willing and able to take the financial risks involved with building and operating large-scale solar thermal plants. These assets seem to clearly outweigh the not so favorable solar resources with Denmark having the lowest irradiance levels among the four countries. Solar resources alone are not a good predictor for the success of largescale solar thermal systems.

China, Germany and Austria have fewer installed systems than Denmark, but a broader range of applications encompassing rural and urban networks and industrial applications. This is partly due to investment-based subsidies which are not bound to a particular application and also allow for more expensive plants as subsidies usually cover a fixed percentage of the total investment cost. Contrary to Denmark, solar process heat applications are eligible for subsidies and Germany has even special promotion schemes for solar process heat applications.

The conditions for solar thermal integration in DH networks in China, Germany and Austria are not as favorable as in Denmark. DH is more widespread in Germany and Austria than in China, but DH temperature levels are generally high. In China, a high heat demand in cold areas with high irradiance levels is contrasted by DH networks which are only in operation in winter and do not provide DHW. The special role of DH utilities as project developers and risk takers for large-scale solar thermal systems is addressed in these countries by special business models, e.g. bioenergy village in Germany and ESCo in Austria. Learning from the Danish experience, providing incentives to $\mathrm{DH}$ utilities to reduce $\mathrm{CO}_{2}$ emissions with market-based instruments (taxes on fossil fuels, emissions trading systems) could be an effective strategy for other countries as well. Compared to investment-based incentives, market-based incentives provide a direct motivation to build the most cost-effective systems and maximize the solar yield.

Collector designs, hydraulic layouts and plant control strategies have been optimized for large applications, making large-scale collector arrays a reliable and mature technology with a broad range of

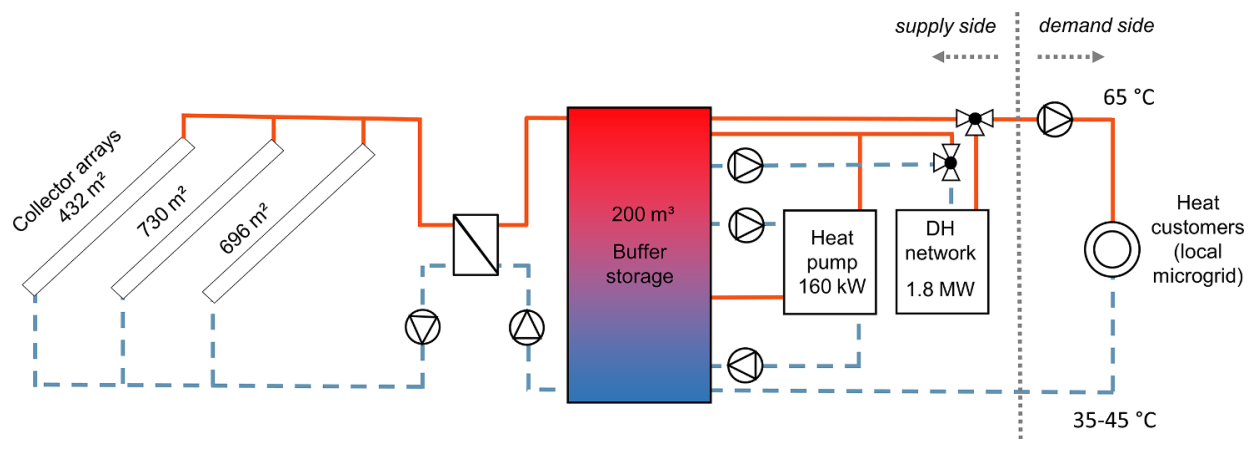

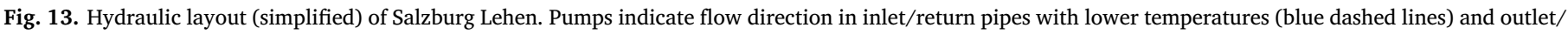
supply pipes with higher temperatures (red solid lines) (source: AEE INTEC). 


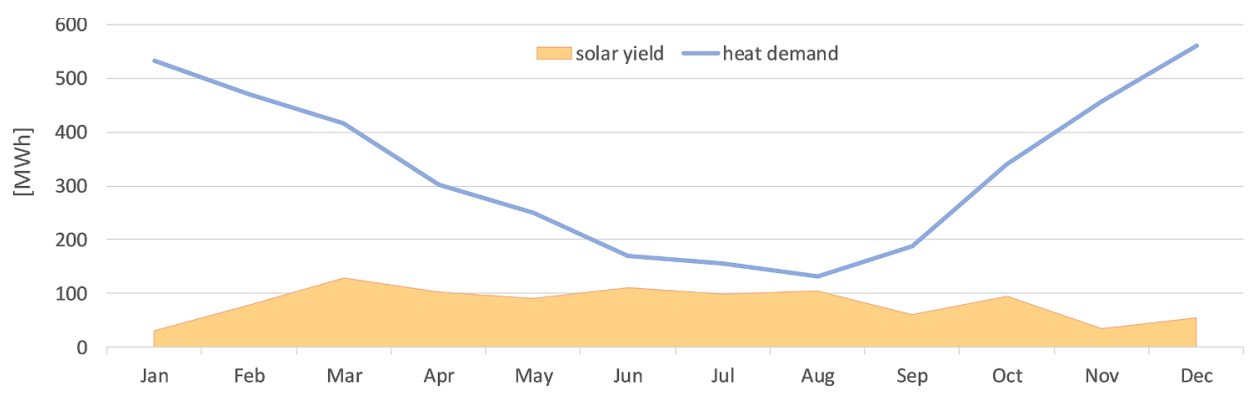

Fig. 14. Monthly solar yield (including indirect solar energy use by heat pump) and heat demand of Salzburg Lehen.

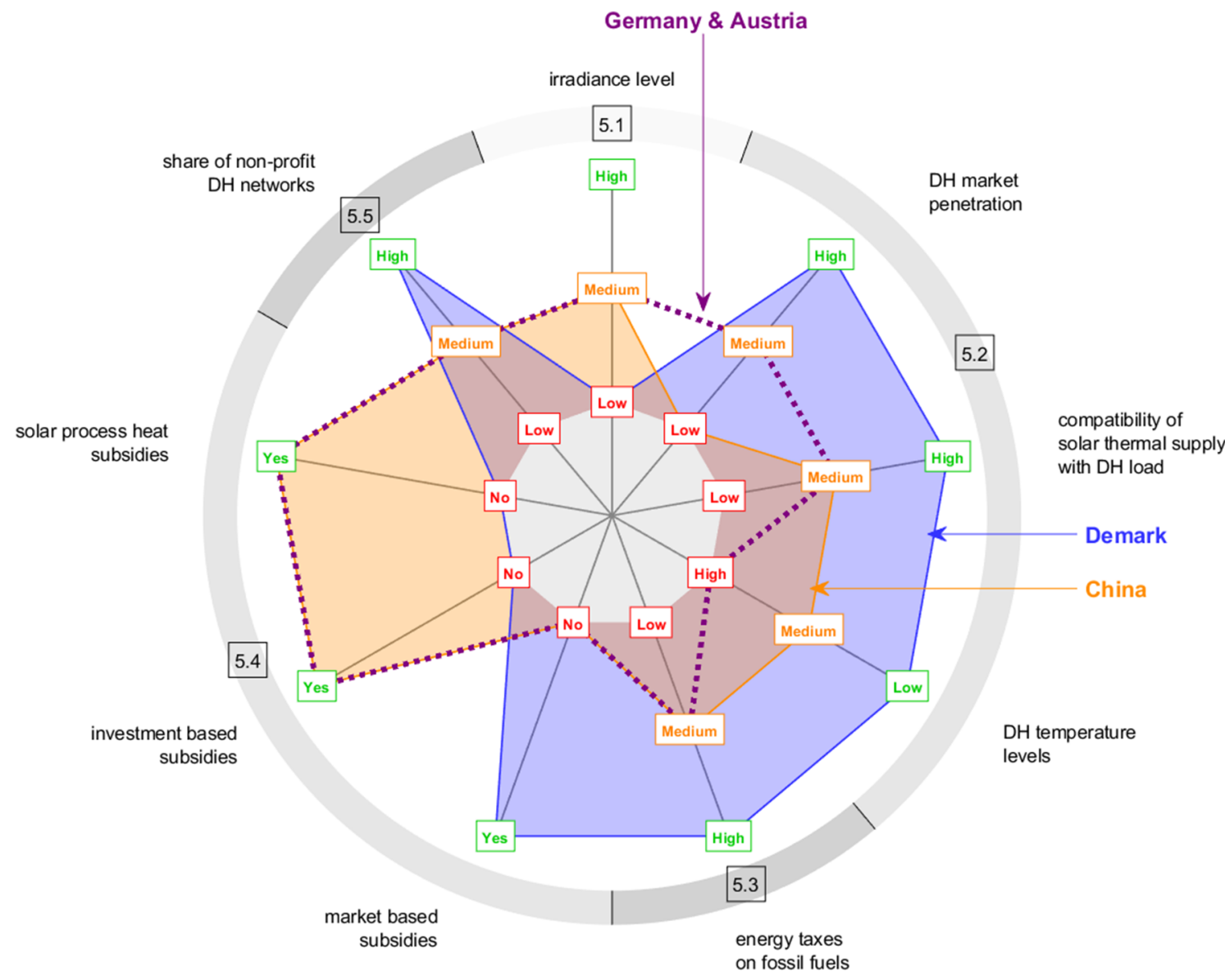

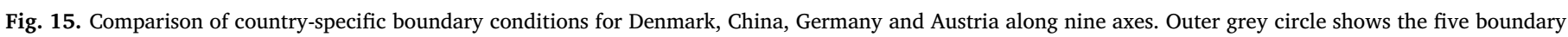
condition categories (see Sections 5.1-5.5) these axes belong to.

applications. Denmark, China, Germany and Austria have built systems which can serve as best practice examples for the solar thermal technology. The Chinese market is very broad regarding collector technology (ETC, CPC, PTC, FPC). A new market dynamic could evolve where FPCs play a predominant role if recent projects like Langkazi Tibet Solar Heating prove viable and convincing. Joint-ventures will result in technology transfer and cost reductions.

Further developments will presumably not focus mainly on component development, but on optimal use of available technologies. In a pilot plant in the Danish town Taars which was put into operation in August 2015, FPCs and PTCs have been combined for the first time [126]. The plant consists of $5,960 \mathrm{~m}^{2}$ FPCs (of which half are singleglazed without foil, half are single-glazed with foil) and 4,039 $\mathrm{m}^{2}$ PTCs connected in series [127]. Each collector type operates on a temperature level where its efficiency is high (FPCs between 40 and $75^{\circ} \mathrm{C}$, PTCs between 75 and $95^{\circ} \mathrm{C}$ ) [128]. Another pilot plant in Condat-sur-Vezere in France with 3.4 MW installed capacity, providing heat to a local paper mill, uses a one-axis tracking system for FPCs for the first time on a large-scale [129]. The use of other collector technologies like Photovoltaic thermal hybrid (PVT) collectors may also be suitable for largescale applications in DH networks, as a recent study shows [130].

In the smart cross-sector energy system of the future, which links smart electricity and thermal and gas grids, there will be an increased interaction of solar thermal heat supply with other technologies, e.g. electric heat pumps driven by wind power or excess wind power converted to heat (power-to-heat) [75]. Digitalisation provides an opportunity to reduce the overall cost of decarbonizing DH by optimizing the operation and introduction of new business models [131]. Economic and environmental potential analyses for solar assisted central heating plants in the EU residential sector showed that a solar fraction above $90 \%$ can be achieved for many EU climate zones [132]. With more and more penetration of volatile renewable electricity such as photovoltaic and wind into electricity grids in the near future, the mismatch of electricity supply and demand will increase. Long-term and short-term 
thermal storages are a cost-efficient option to add flexibility, as electricity storage is much more expensive than thermal storage [133]. Seasonal heat storages can be used both for solar heat and for excess electricity converted to heat, which increases the number of load cycles and reduces the cost of storages [3]. Seasonal thermal energy storage systems should be further analyzed to make solar heat available in winter [134]. In energy systems with a high share of renewables, solar thermal heat supply will compete with other renewable technologies. Here, the advantage to save $\mathrm{CO}_{2}$ emissions compared to fossil fuels is not decisive anymore and needs to be replaced by other reasons, e.g. easing the pressure on scarce renewable resources like biomass [6]. Large-scale solar thermal systems which are part of district energy systems can benefit from 4th generation DH networks with supply temperatures of $40-50{ }^{\circ} \mathrm{C}$, or even lower [85]. Low supply temperatures increase the efficiency of collectors and increase the storage capacity and utilization.

An advantage which is largely neglected is the long-term price stability of large-scale solar thermal systems as O\&M costs are very low. Solar thermal heat supply is typically associated with high financial risks. The use of risk minimizing strategies could turn the perceived disadvantage into an asset.

\section{Conclusion}

In this paper, a comprehensive overview of the market and common technological solutions for large-scale solar thermal systems in Denmark, China, Germany and Austria is provided. Country-specific factors which put these four countries in the leading position regarding large-scale solar thermal systems are analyzed and a best practice example for each country is introduced in detail. The following conclusions may be drawn:

- Denmark is the leading country for solar district heating applications. A major part of the Danish success story is due to the unique role of district heating utilities, which are mostly non-profit and oftentimes act both as investors and operators of large-scale solar thermal systems. District heating utilities are given motivation to build solar thermal plants by high taxes on fossil fuels and a national $\mathrm{CO}_{2}$ emissions trading scheme especially designed for energy distribution companies.

- China, Germany and Austria have a broader variety of large-scale solar thermal applications including solar process heat, partly due to incentive schemes based on installation cost of plants rather than market-based instruments like in Denmark.

- Differences in the availability of solar resources are a minor factor for the success of large-scale solar thermal systems in these countries, but rather the heat supply infrastructure (for district heating) and relative prices to competing technologies and promotion schemes are important.

- Besides low cost for solar heat provision, risk minimizing strategies are an important, often underestimated success factor to deal with the problem of high initial investment costs. Successful risk minimizing strategies are improved solar yield and heat load predictions and performance guarantees, turn-key suppliers, energy service companies and energy cooperatives. Risk-taking by district heating utilities like in Denmark can push the market.

- Heat supply from large-scale solar thermal systems is a mature technology with a broad field of applications. Optimized solutions for large collector arrays to realize economies of scale include hydraulic layouts leading to homogenous flow distribution and modelbased plant control with frequency-controlled pump.

Recommendations for the future:

- District heating utilities should be targeted with market-based instruments and given incentives or economic motivation to reduce
$\mathrm{CO}_{2}$ emissions. Non-profit orientation of operators can help to induce long-term investments.

- Market and solar yield-based incentives should have priority over investment-based incentives. The latter should be used, when national energy policies do not allow to target the $\mathrm{CO}_{2}$ emitter in the short run, e.g. the industrial sector.

- Widespread use of risk minimizing strategies for investors should be regarded in solar business models.

- Long-term price stability of solar thermal heat supply due to low operation and maintenance costs and the long life time of solar collectors should be stressed more in solar thermal promotion strategies.

- The role of large-scale solar thermal systems in future energy systems needs to be evaluated on a system level, including the interaction with the electricity sector.

\section{Acknowledgements}

The authors would like to express their gratitude to the following people and institutes for the contribution of data or material used in this paper: Samuel Knabl (AEE INTEC), Philip Ohnewein (AEE INTEC), Franz Mauthner (AEE INTEC), Marnoch Hamilton-Jones (AEE INTEC), Harald Poscharnig (GREENoneTEC GmbH), Dirk Mangold (Solites), Bärbel Epp (Solrico), Alexander Thür (University of Innsbruck), Wolfgang Streicher (University of Innsbruck); China Academy of Building Research (Bojia Li, Tao He), Linuo (Wanli Yuan), Chinese Academy of Sciences (Guofeng Yuan), IMSIA (Junpeng Huang), Sunrain (Qingtai Jiao, Kaichun Li).

This research work contributes to IEA SHC Task 55 - Towards the Integration of Large SHC Systems into District Heating and Cooling (DHC) Networks. Daniel Tschopp was supported by the Austrian Research Promotion Agency with the PhD scholarship project CollFieldEff ${ }^{+}$(FFG 854735).

\section{Author contribution}

Daniel Tschopp and Zhiyong Tian proposed the idea for this paper. Daniel Tschopp wrote the part on Austria and coordinated the description of key features of wide-spread technological solutions of largescale solar thermal systems. Zhiyong Tian wrote the parts on Denmark and China. Magdalena Berberich wrote the part on Germany. Jianhua Fan contributed to the data collection on China. Bengt Perers and Simon Furbo contributed to the data collection on Denmark. Jianhua Fan, Bengt Perers and Simon Furbo revised the paper. Daniel Tschopp and Zhiyong Tian organized and wrote the final manuscript.

\section{References}

[1] International Energy Agency. Key world energy statistics. Paris: International Energy Agency; 2018.

[2] Eurostat. Share of fuels in the final energy consumption in the residential sector, 2016 (nrg_110a). Updated 31 May 2018. Eurostat; 2016.

[3] Tian Z, Zhang S, Deng J, Fan J, Huang J, Kong W, et al. Large-scale solar district heating plants in Danish smart thermal grid: Developments and recent trends. Energy Convers Manage 2019;189:67-80. https://doi.org/10.1016/j.enconman. 2019.03.071.

[4] Sanner B, Angelino L, De Gregorio M, Février N, Haslinger W, Kujbus A, et al. Strategic research and innovation agenda for renewable heating \& cooling. Brussels: Secretariat of the RHC-Plattform; 2013.

[5] International Energy Agency. Technology Roadmap Solar Heating and Cooling. Paris: International Energy Agency; 2012.

[6] Mathiesen, BV, Hansen, K. The role of solar thermal in future energy systems. Country Cases for Germany, Italy, Austria and Denmark. Aalborg: Aalborg University; 2017.

[7] China Energy Portal. Opinions on promoting renewable energy based heat supply [in Chinese]. China Energy Portal; 2017. https://chinaenergyportal.org/opinionson-promoting-renewable-energy-based-heat-supply-draft-for-comments/ [accessed August 15, 2019].

[8] Weiss W, Spörk-Dür M. Solar Heat Worldwide. Global Market Development and Trends in 2018. Detailed Market Figures 2017. 2019 Edition Gleisdorf: AEE Institute for Sustainable Technologies; 2018.

[9] Mauthner F, Herkel S. Technology and Demonstrators. Technical Report Subtask C, 
Part C1. Classification and benchmarking of solar thermal systems in urban environments. IEA SHC Task 52. Gleisdorf: AEE - Institute for Sustainable Technologies; 2016

[10] Renaldi R, Friedrich D. Techno-economic analysis of a solar district heating system with seasonal thermal storage in the UK. Appl Energy 2019;236:388-400. https:// doi.org/10.1016/j.apenergy.2018.11.030.

[11] International Energy Agency. Recommendation: Converting solar thermal collector area into installed capacity $\left(\mathrm{m}^{2}\right.$ to $\left.\mathrm{kW}_{\mathrm{th}}\right)$. Available online: https://www.ieashc.org/Data/Sites/1/documents/statistics/Technical_Note-New_Solar_Thermal_ Statistics_Conversion.pdf. 2004.

[12] AEE INTEC. Evaluation of Solar Heat for Industrial Processes (SHIP) database (http://ship-plants.info/solar-thermal-plants). Unpublished. Gleisdorf: AEE Institute for Sustainable Technologies; 2019.

[13] AEE INTEC. Calculation based on "Solar Heat Worldwide" Editions 2012-2019. Gleisdorf: AEE INTEC; 2019.

[14] Perez-Mora N, Bava F, Andersen M, Bales C, Lennermo G, Nielsen C, et al. Solar district heating and cooling: A review. Int J Energy Res 2018;42:1419-41. https:// doi.org/10.1002/er.3888.

[15] Müller A, Büchele R, Kranzl L, Totschnig G, Mauthner F, Heimrath R, et al Solarenergie und Wärmenetze: Optionen und Barrieren in einer langfristigen, in tegrativen Sichtweise. Endbericht des Projekts SolarGrids. Wien: TU Wien - EEG; 2014.

[16] Weiss W, Spörk-Dür M Solar heat worldwide. Global market development and trends in 2017. Detailed market figures 2016. Edition Gleisdorf: AEE - Institute for Sustainable Technologies; 2018.

[17] van der Heijde B, Vandermeulen A, Salenbien R, Helsen L. Representative days selection for district energy system optimisation: a solar district heating system with seasonal storage. Appl Energy 2019;248:79-94. https://doi.org/10.1016/j. apenergy.2019.04.030.

[18] Trier D, Skov CK, Sørensen SS. Solar district heating. Trends and possibilities. Characteristics of ground-mounted systems for screening of land use requirements and feasibility. Technical report of IEA SHC task 52, Subtask B. Copenhagen: PlanEnergi; 2018.

[19] Dalenbäck J-O. Success factors in solar district heating. WP 2 - micro analyses report. Deliverable D2.1. Gothenburg. CIT Energy Management AB 2010.

[20] Fan J, Chen Z, Furbo S, Perers B, Karlsson B. Efficiency and lifetime of solar collectors for solar heating plants. In: Proceedings of the ISES solar world congress; 2009.

[21] de Vries BJM, van Vuuren DP, Hoogwijk MM. Renewable energy sources: Their global potential for the first-half of the 21st century at a global level: An integrated approach. Energy Policy 2007;35:2590-610. https://doi.org/10.1016/j.enpol. 2006.09.002

[22] Strantzali E, Aravossis K. Decision making in renewable energy investments: A review. Renew Sustain Energy Rev 2016;55:885-98. https://doi.org/10.1016/j. rser.2015.11.021.

[23] Nielsen JE, Sørensen PA. Renewable district heating and cooling technologies with and without seasonal storage. Renewable heating and cooling Woodhead Publishing; 2016. p. 197-220. https://doi.org/10.1016/B978-1-78242-213-6. 00009-6.

[24] Dalenbäck J-O, Werner S. Market for solar district heating. WP 2 - European market study. Deliverable D2.3. Gothenburg: CIT Energy Management AB; 2012

[25] Vejen NK, Furbo S, Shah LJ. Development of $12.5 \mathrm{~m}^{2}$ solar collector panel for solar heating plants. Sol Energy Mater Sol Cells 2004;84:205-23. https://doi.org/10. 1016/j.solmat.2004.01.037.

[26] Pandey KM, Chaurasiya R. A review on analysis and development of solar flat plate collector. Renew Sustain Energy Rev 2017;67:641-50. https://doi.org/10.1016/j. rser.2016.09.078.

[27] Bava F, Furbo S, Perers B. Simulation of a solar collector array consisting of two types of solar collectors, with and without convection barrier. Energy Procedia 2015;70:4-12. https://doi.org/10.1016/j.egypro.2015.02.091.

[28] Fuqiang W, Ziming C, Jianyu T, Yuan Y, Yong S, Linhua L. Progress in concentrated solar power technology with parabolic trough collector system: A comprehensive review. Renew Sustain Energy Rev 2017;79:1314-28. https://doi. org/10.1016/j.rser.2017.05.174.

[29] Personal communication Harald Poscharnig, GREENoneTEC, 2019-05-27.

[30] Knabl S, Fink C, Ohnewein P, Mauthner F, Hausner R. Requirements \& guidelines for collector loop installation. IEA-SHC TECH SHEET 45.A.2. Gleisdorf: AEE Institute for Sustainable Technologies; 2014.

[31] Glembin J, Eggert D, Rockendorf G, Scheuren J. Evaporation in solar thermal collectors during operation. Reasons and effects of partial stagnation. J Sol Energy Eng 2011;133:1-9. https://doi.org/10.1115/1.4004384.

[32] Fan J, Furbo S. Buoyancy effects on thermal behavior of a flat-plate solar collector. J Sol Energy Eng 2008;130:1-2. https://doi.org/10.1115/1.2840611.

[33] Bava F, Dragsted J, Furbo S. A numerical model to evaluate the flow distribution in a large solar collector field. Sol Energy 2017;143:31-42. https://doi.org/10.1016/ j.solener.2016.12.029.

[34] Rühling K, Heymann M, Panitz F. Venting and degasification of solar circuits. Energy Procedia 2012;30:815-23. https://doi.org/10.1016/j.egypro.2012.11.092.

[35] Camacho EF, Berenguel M. Control of solar energy systems. IFAC Proceedings Volumes 2012;45:848-55.

[36] Camacho EF, Berenguel M, Rubio FR, Martínez D. Control of solar energy systems. London: Springer; 2012.

[37] Bava F, Furbo S. Impact of different improvement measures on the thermal performance of a solar collector field for district heating. Energy 2018;144:816-25. https://doi.org/10.1016/j.energy.2017.12.025.

[38] Lemos JM, Neves-Silva R, Igreja JM. Adaptive control of solar energy collector systems. Cham: Springer; 2014.

[39] Berberich M, Mangold D. Solar district heating in Europe: supplying renewable zero-emission heat. Proceedings of IEA SHC, Abu Dhabi, UAE. 2017.

[40] Fink C, Preis D. Roadmap "Solarwärme 2025". Eine Technologie- und
Marktanalyse mit Handlungsempfehlungen. Berichte aus Energie- und Umweltforschung 42/2014. Wien: BMVIT; 2014.

[41] TRNSYS 17. A transient system simulation program. Madison: Solar Energy Laboratory, Univ. of Wisconsin-Madison; 2012

[42] Polysun. Winterthur: Vela Solaris AG; 2019.

[43] European Solar Thermal Industry Federation (ESTIF). SOLAR KEYMARK Scheme Rules. SKY NO444R1. Edition 2019-03-07. Brussels: ESTIF; 2019.

[44] Tschopp D, Ohnewein P, Hausner R, Rohringer C. In-situ testing of large collector arrays - challenges and methodological framework. In: Proceedings of SWC2017/ SHC2017, Abu Dhabi: International Solar Energy Society; 2017, p. 1-10. https:// doi.org/10.18086/swc.2017.36.03.

[45] Fahr S, Gumbel U, Zirkel-Hofer A, Kramer K. In Situ Characterization of Thermal Collectors in Field Installations. Proceedings of EuroSun 2018, Rapperswil: International Solar Energy Society; 2018, p. 1-10. https://doi.org/10.18086/ eurosun2018.12.01.

[46] Dotzauer E. Simple model for prediction of loads in district-heating systems. Appl Energy 2002;73:277-84.

[47] Zhao H, Magoulès F. A review on the prediction of building energy consumption. Renew Sustain Energy Rev 2012;16:3586-92. https://doi.org/10.1016/j.rser. 2012.02.049.

[48] Gueymard CA. A review of validation methodologies and statistical performance indicators for modeled solar radiation data: Towards a better bankability of solar projects. Renew Sustain Energy Rev 2014;39:1024-34. https://doi.org/10.1016/j. rser.2014.07.117.

[49] Lohmann S, Schillings C, Mayer B, Meyer R. Long-term variability of solar direct and global radiation derived from ISCCP data and comparison with reanalysis data. Sol Energy 2006;80:1390-401. https://doi.org/10.1016/j.solener.2006.03. 004.

[50] Nikitidou E, Kazantzidis A, Salamalikis V. The aerosol effect on direct normal irradiance in Europe under clear skies. Renewable Energy 2014;68:475-84. https:// doi.org/10.1016/j.renene.2014.02.034.

[51] Nielsen JE, Trier D. Guaranteed power output. IEA-SHC TECH SHEETS 45.A.3.1. Copenhagen: PlanEnergi; 2014.

[52] PlanEnergi. Large-scale solar thermal sytems in Denmark. Data 2010 - 2018. Copenhagen: PlanEnergi; 2019.

[53] Solites. Large-scale solar thermal systems in Germany. Data 2010 - 2018. Stuttgart: Solites; 2019.

[54] AEE - Institute for Sustainable Technologies. Large-scale solar thermal systems in Austria. Data 2010 - 2018. Gleisdorf: AEE - Institute for Sustainable Technologies; 2019.

[55] Deschaintre L, Miedaner O, Pauschinger T, Winterscheid C. The many faces of solar district heating in Germany, Graz: Proceedings of 5th Solar District Heating Conference, 2018, p. 190-5.

[56] Galindo Fernandez M, Rohger-Lacan C, Gährs U, Aumaitre V. Efficient district heating and cooling systems in the EU. Case studies analysis, replicable key success factors and potential policy implications. Luxembourg: Publications Office of the European Union; 2016.

[57] Danish Energy Agency. Regulation and Planning of district heating in Denmark. København: Danish Energy Agency; 2016.

[58] Unger EA, Ulfarsson GF, Gardarsson SM, Matthiasson T. A long-term analysis studying the effect of changes in the Nordic electricity supply on Danish and Finnish electricity prices. Econ Anal Policy 2017;56:37-50. https://doi.org/10. 1016/j.eap.2017.06.001.

[59] Eurostat. Electricity prices for household consumers - bi-annual data (from 2007 onwards) (nrg_pc_204). Updated 24-02-2020. Eurostat; 2020.

[60] Furbo S, Dragsted J, Perers B, Andersen E, Bava F, Nielsen KP. Yearly thermal performances of solar heating plants in Denmark - Measured and calculated. Sol Energy 2018;159:186-96. https://doi.org/10.1016/j.solener.2017.10.067.

[61] Ritter XL Solar. Solare Großanlagen; 2019. http://ritter-xl-solar.com/ [accessed June 8, 2017].

[62] Solites. Saisonalspeicher. http://www.saisonalspeicher.de/ [accessed August 15, 2019].

[63] Solare Prozesswärme. Solar heat for industrial processes (SHIP) plants database. http://www.solare-prozesswärme.info/markt/ [accessed August 15, 2019].

[64] Fink C, Knabl S, Stelzer R, Windholz B, Helminger F. Aggregierte Ergebnisse aus der wissenschaftlichen Begleitung des Förderprogramms "Solare Großanlagen" in Österreich. Bad Staffelstein: OTTI Symposium Thermische Solarenergie; 2017.

[65] Arcon Sunmark. http://arcon-sunmark.com/ [accessed August 15, 2019].

[66] Huang J, Tian Z, Fan J. A comprehensive analysis on development and transition of the solar thermal market in China with more than $70 \%$ market share worldwide. Energy 2019;174:611-24. https://doi.org/10.1016/j.energy.2019.02.165.

[67] Epp B. World's largest flat plate collector manufacturers in 2018. Solarthermalworld; 2019. https://www.solarthermalworld.org/content/worldslargest-flat-plate-collector-manufacturers-2018 [accessed August 15, 2019].

[68] Epp B. China: Arcon-Sunmark and Sunrain Establish Joint-Venture for Large Projects. Solarthermalworld; 2016. https://www.solarthermalworld.org/content/ china-arcon-sunmark-and-sunrain-establish-joint-venture-large-projects [accessed August 15, 2019].

[69] Biermayr P, Dissauer C, Eberl M, Fechner H, Fischer L, Leonhartsberger K, et al. Innovative Energietechnologien in Österreich. Marktentwicklung 2017. Wien: Bundesministerium für Verkehr, Innovation und Technologie; 2018.

[70] Epp B. Austria: Haier now holds $51 \%$ stake in Greenonetec. Solarthermalworld; 2017. https://www.solarthermalworld.org/content/austria-haier-now-holds-51stake-greenonetec [accessed August 15, 2019].

[71] Ahlgren B, Tian Z, Perers B, Dragsted J, Johansson E, Lundberg K, et al. A simplified model for linear correlation between annual yield and DNI for parabolic trough collectors. Energy Convers Manage 2018;174:295-308. https://doi.org/10. 1016/j.enconman.2018.08.008.

[72] Epp, B. Acquisition of strategic importance. Solarthermalword; 2020. https:// www.solarthermalworld.org/news/acquisition-strategic-importance [accessed 
April 3, 2020].

[73] Perers B, Zinko H, Holst P. Analytical model for the daily energy input output relationship for solar collector systems. Stockholm: Swedish Council for Building Research; 1985.

[74] Connolly D, Mathiesen BV, Østergaard PA, Möller B, Nielsen S, Lund H, et al. Heat Map Europe 2050. Study for the EU27. Euroheat \& Power; 2012.

[75] Tian Z, Perers B, Furbo S, Fan J, Deng J, Dragsted J. A comprehensive approach for modelling horizontal diffuse radiation, direct normal irradiance and total tilted solar radiation based on global radiation under Danish climate conditions. Energies 2018;11:1-19. https://doi.org/10.3390/en11051315.

[76] Riddersholm Wang P. Referenceværdier: Måneds- og årskort 2001 - 2010 , Danmark for temperatur, relativ luftfugtighed, vindhastighed, globalstråling og nedbør. Teknisk Rapport 12-23. København: DMI; 2013.

[77] Laursen EV, Thomsen RS, Cappelen J. Observed air temperature, humidity, pres sure, cloud cover and weather in Denmark: with climatological standard normals 1961-90. Copenhagen: Danish Meteorological Institute; 1999.

[78] Solar GIS. Solar resource maps of China. Solar Resource Maps and GIS Data for $180+$ Countries 2019. https://solargis.com/maps-and-gis-data/download/china [accessed August 15, 2019]

[79] Li Y, Liao S, Rao Z, Liu G. A dynamic assessment based feasibility study of concentrating solar power in China. Renewable Energy 2014;69:34-42. https://doi. org/10.1016/j.renene.2014.03.024.

[80] Solar GIS. Solar resource maps of Germany. Solar resource maps and GIS data for $180+$ countries 2019. https://solargis.com/maps-and-gis-data/download/ germany [accessed August 15, 2019].

[81] Deutscher Wetterdienst DWD. Wetter und Klima - Deutscher Wetterdienst Leistungen - Zeitreihen und Trends; n.d. https://www.dwd.de/DE/leistungen/ zeitreihenundtrends/zeitreihenundtrends.html?nn =16102 [accessed August 15, 2019].

[82] Solar GIS. Solar resource maps of Austria. Solar Resource Maps and GIS Data for $180+$ Countries; 2019. https://solargis.com/maps-and-gis-data/download/ austria [accessed August 15, 2019].

[83] ZAMG. Klima aktuell; n.d. http://www.zamg.ac.at/cms/de/klima/klima-aktuell/ klimatothek [accessed August 15, 2019].

[84] Heller AJ. Heat-load modelling for large systems. Appl Energy 2002;72:371-87. https://doi.org/10.1016/S0306-2619(02)00020-X.

[85] Lund H, Werner S, Wiltshire R, Svendsen S, Thorsen JE, Hvelplund F, et al. 4th Generation District Heating (4GDH). Energy 2014;68:1-11. https://doi.org/10. 1016/j.energy.2014.02.089.

[86] International Energy Agency. District Energy Systems in China. Options for opti misation and diversification. Paris: International Energy Agency; 2017.

[87] Werner S. International review of district heating and cooling. Energy 2017;137:617-31. https://doi.org/10.1016/j.energy.2017.04.045.

[88] Design code for heating ventilation and air conditioning of civil buildings. Beijing: Ministry of Housing and Urban-Rural Development of the People's Republic of China; 2012.

[89] Umweltbundesamt. Energieverbrauch für fossile und erneuerbare Wärme; 2018 https://www.umweltbundesamt.de/daten/energie/energieverbrauch-fuer-fossileerneuerbare-waerme\#textpart-1 [accessed August 15, 2019].

[90] Arbeitsgruppe Erneuerbare Energien-Statistik. Erneuerbaren Energien in Deutschland Daten zur Entwicklung im Jahr 2017. Dessau-Roßlau: Umweltbundesamt; 2018.

[91] BDEW Bundesverband der. Energie- und Wasserwirtschaft e.V. Strategiepapie "Zukunft Wärmenetzsysteme". Berlin: BDEW; 2017.

[92] Statistik Austria. Energetischer Endverbrauch 2016 nach Energieträgern und Nutzenergiekategorien für Österreich; 2017.

[93] Statistik Austria. Gesamtenergiebilanz Österreich 1970 bis 2016 (Detailinformation); 2017.

[94] Euroheat \& Power. District Heating and Cooling Country-by-Country. 2017 Survey. Brussels: Euroheat \& Power; 2017.

[95] Renewable energy in district heating and cooling: A sector roadmap for REmap. Abu Dhabi. International Renewable Energy Agency; 2017.

[96] Faninger G. Combined solar-biomass district heating in Austria. Sol Energy 2000;69:425-35. https://doi.org/10.1016/S0038-092X(00)00117-1.

[97] European Commission, editor. Energy roadmap 2050. Luxembourg: Publications Office of the European Union; 2012.

[98] Reiter P, Poier H, Holter C. BIG solar Graz: solar district heating in Graz - 500,000 $\mathrm{m}^{2}$ for 20\% Solar Fraction. Energy Procedia 2016;91:578-84. https://doi.org/10. 1016/j.egypro.2016.06.204.

[99] Gudmundsson O, Thorsen JE, Zhang L. Cost analysis of district heating compared to its competing technologies. WIT Transactions on Ecology and the Environment, vol. 176, Bucharest: 2013, p. 3-13. https://doi.org/10.2495/ESUS130091.

[100] Ganapathy V. Industrial boilers and heat recovery steam generators: design, applications, and calculations 2002

[101] International Energy Agency. Energy policies of IEA countries - Denmark 2017 review. Paris: International Energy Agency; 2017.

[102] Keränen J, Alakangas E. Report on the competition and price situation of woody biomass use in forest industry and energy sector - D7.1. VTT-R-02376-11. Espoo: VTT Technical Research Centre of Finland; 2011.

[103] Schrammel H, Metz S, Spörk-Dür M, Promitzer F. Evaluierung der Maßnahme 321 C. Gleisdorf: AEE - Institute for Sustainable Technologies; 2015.

[104] Paltsev S, Zhang D. Natural gas pricing reform in China: Getting closer to a market system? Energy Policy 2015;86:43-56. https://doi.org/10.1016/j.enpol.2015.06. 027.

[105] Wang Q, Chen X. China's electricity market-oriented reform: From an absolute to a relative monopoly. Energy Policy 2012;51:143-8. https://doi.org/10.1016/j. enpol.2012.08.039.

[106] Fridley D, Lu H, Xu L. Key China Energy Statistics 2016. Berkeley: Lawrence Berkeley National Laboratory; 2017.

[107] Brocs JS. Energy Companies' Energy-Saving Efforts in Denmark. case study prepared by IEECP for the EPATEE project, funded by the European Union's Horizon 2020 programme; 2017. https://Epatee.Eu/System/Tdf/Epatee_case_study denmark_eeo_scheme_ok_0.Pdf?File $=1 \&$ type $=$ node\&id $=67$.

[108] Klima-, Energi- og Forsyningsministeriet. Bekendtgørelse om energispareydelser i net- og distributionsvirksomheder (Implementing Regulations on Energy Saving Services in Network and Distribution Companies). BEK nr 864 af 26/08/2019 (Gældende); n.d.

[109] Bundesministerium für Wirtschaft und Energie. Zweiter Fortschrittsbericht zur Energiewende - Die Energie der Zukunft. Berichtsjahr 2017. Berlin: BMWi; 2017.

[110] Bundesministerium für Wirtschaft und Energie. Energieeffizienzstrategie Gebäude. Berlin: BMWi; 2015.

[111] Bundesministerium für Wirtschaft und Energie. Richtlinien zur Förderung von Maßnahmen zur Nutzung erneuerbarer Energien im Wärmemarkt. Berlin: BMWi; 2015 .

[112] Bundesministerium für Wirtschaft und Energie. Förderbekanntmachung zu den Modellvorhaben Wärmenetzsysteme 4.0 ("Wärmenetze 4.0"); 2017.

[113] Bundesministeriumfür Wirtschaft und Energie. Richtliniefür die Bundesförderung der Energieeffizienz und Prozesswärmeaus Erneuerbaren Energien in der Wirtschaft-Wettbewerb(BMWi-Wettbewerb Energieeffizienz (BAnz AT 29.03. 2019 B1). Berlin: BMWi; 2019.

[114] European Union. Directive 2009/28/EC of the European Parliament and of the Council of 23 April 2009 on the promotion of the use of energy from renewable sources and amending and subsequently repealing Directives 2001/77/EC and 2003/30/EC. Official Journal of the European Union 2009;5.

[115] Fink C, Müller T, Weiss W. Solarwärme 2020. Eine Technologie- und Umsetzungsroadmap für Österreich. Wien: Lebensministerium; 2008.

[116] Klima- und Energiefonds. Leitfaden Solarthermie - solare Großanlagen. 8. Ausschreibung Eine Förderaktion des Klima- und Energiefonds der österreichischen Bundesregierung. Wien: Klima- und Energiefonds; 2017.

[117] PlanEnergi, Danish District Heating Association. Solar District Heating Inspiration and Experiences from Denmark. Copenhagen: PlanEnergi; 2018.

[118] Solites. SDHplus Bioenergy villages Germany. Stuttgart: Solites; 2013.

[119] Bundesministerium für Wirtschaft und Energie. Erneuerbare-EnergienWärmegesetz - EEWärmeG; 2018.

[120] Fink C, Knabl S, Wagner W, Stelzer R, Windholz B, Schöffmann P, et al. Aggregierte Ergebnisse zum Projekt "Wissenschaftliche Begleitforschung zum Förderprogramm "Solarthermie - Solare Großanlagen” 2010-2015. Gleisdorf: AEE - Institute for Sustainable Technologies; 2016.

[121] Winterscheid C, Schmidt T. Dronninglund district heating monitoring data evaluation for the years 2015-2017. Stuttgart Solites; 2019.

[122] Klöck M. Messdatenauswertung der solaren Nahwärmeversorgung Büsingen. Stuttgart: Solites; 2016.

[123] Solites AGFW. Case Study: SDH plant Bioenergiedorf Büsingen (Germany). Stuttgart: Solites; 2013.

[124] Tschopp D. Solarthermische Grossanlagen - Betriebsanalyse, Systemevaluation, Bewertungsmethoden, Benchmarking. Fachhhochschule Burgenland, 2015.

[125] Chang TP. The Sun's apparent position and the optimal tilt angle of a solar collector in the northern hemisphere. Sol Energy 2009;83:1274-84. https://doi.org/ 10.1016/j.solener.2009.02.009.

[126] Tian Z, Perers B, Furbo S, Fan J. Analysis and validation of a quasi-dynamic model for a solar collector field with flat plate collectors and parabolic trough collectors in series for district heating. Energy 2018;142:130-8. https://doi.org/10.1016/j. energy.2017.09.135.

[127] Tian Z, Perers B, Furbo S, Fan J. Annual measured and simulated thermal performance analysis of a hybrid solar district heating plant with flat plate collector and parabolic trough collectors in series. Appl Energy 2017;205:417-27. https:// doi.org/10.1016/j.apenergy.2017.07.139.

[128] Tian Z, Perers B, Furbo S, Fan J. Thermo-economic optimization of a hybrid solar district heating plant with flat plate collectors and parabolic trough collectors in series. Energy Convers Manage 2018;165:92-101. https://doi.org/10.1016/j. enconman.2018.03.034.

[129] Savosolar hands over 3.3-MW solar thermal system in France. https:// renewablesnow.com/news/savosolar-hands-over-33-mw-solar-thermal-system-infrance-653639/ [accessed August 15, 2019].

[130] Pakere I, Ziemele J, Blumberga D. DH company in prosumers role. Energy Procedia 2017;128:234-9. https://doi.org/10.1016/j.egypro.2017.09.061.

[131] Lyons L. Digitalisation: Opportunities for heating and cooling. JCR Technical Reports. Luxembourg: Publications Office of the European Union; 2019.

[132] Tulus V, Abokersh MH, Cabeza LF, Vallès M, Jiménez L, Boer D. Economic and environmental potential for solar assisted central heating plants in the EU residential sector: Contribution to the 2030 climate and energy EU agenda. Appl Energy 2019;236:318-39. https://doi.org/10.1016/j.apenergy.2018.11.094.

[133] Li Y, Ding Z, Du Y. Techno-economic optimization of open-air swimming pool heating system with PCM storage tank for winter applications. Renewable Energy 2020;150:878-90. https://doi.org/10.1016/j.renene.2020.01.029.

[134] Dahash A, Ochs F, Janetti MB, Streicher W. Advances in seasonal thermal energy storage for solar district heating applications: A critical review on large-scale hotwater tank and pit thermal energy storage systems. Appl Energy 2019;239:296-315. https://doi.org/10.1016/j.apenergy.2019.01.189. 